\title{
Bone Marrow-Derived Mesenchymal Stromal Cells: A Novel Target to Optimize Hematopoietic Stem Cell Transplantation Protocols in Hematological Malignancies and Rare Genetic Disorders
}

\author{
Stefania Crippa ${ }^{1}$, Ludovica Santi ${ }^{1}$, Roberto Bosotti ${ }^{1}$, Giulia Porro ${ }^{1}$ and \\ Maria Ester Bernardo 1,2,* \\ 1 San Raffaele-Telethon Institute for Gene Therapy (SR-TIGET), San Raffaele Scientific Institute, 20132 Milan, \\ Italy; crippa.stefania@hsr.it (S.C.); santi.ludovica@hsr.it (L.S.); bosotti.roberto@hsr.it (R.B.); \\ porro.giulia@hsr.it (G.P.) \\ 2 Pediatric Immunohematology and Bone Marrow Transplantation Unit, San Raffaele Scientific Institute, \\ 20132 Milan, Italy \\ * Correspondence: bernardo.mariaester@hsr.it; Tel.: +39-02-2643-6329; Fax: +39-02-2643-6545
}

Received: 31 October 2019; Accepted: 12 December 2019; Published: 18 December 2019

\begin{abstract}
Mesenchymal stromal cells (MSCs) are crucial elements in the bone marrow (BM) niche where they provide physical support and secrete soluble factors to control and maintain hematopoietic stem progenitor cells (HSPCs). Given their role in the BM niche and HSPC support, MSCs have been employed in the clinical setting to expand ex-vivo HSPCs, as well as to facilitate HSPC engraftment in vivo. Specific alterations in the mesenchymal compartment have been described in hematological malignancies, as well as in rare genetic disorders, diseases that are amenable to allogeneic hematopoietic stem cell transplantation (HSCT), and ex-vivo HSPC-gene therapy (HSC-GT). Dissecting the in vivo function of human MSCs and studying their biological and functional properties in these diseases is a critical requirement to optimize transplantation outcomes. In this review, the role of MSCs in the orchestration of the BM niche will be revised, and alterations in the mesenchymal compartment in specific disorders will be discussed, focusing on the need to correct and restore a proper microenvironment to ameliorate transplantation procedures, and more in general disease outcomes.
\end{abstract}

Keywords: mesenchymal stromal cells; bone marrow niche; hematopoietic stem and progenitor cells; hematopoietic stem cell transplantation; ex-vivo gene therapy

\section{Introduction}

Mesenchymal stromal cells (MSCs) are a rare population of non-hematopoietic multipotent cells resident in the bone marrow (BM), which offer physical support and regulate hematopoietic stem/progenitor cell (HSPC) homeostasis. MSCs were first isolated from the BM [1,2], thanks to their ability to adhere to plastic and generate colony-forming unit fibroblasts (CFU-Fs) in vitro. MSCs can be easily expanded for several passages as fibroblast-like cells. In vitro, they are positive for the expression of specific surface markers, classification determinant (CD)105, CD90, and CD73, whereas they do not express hematopoietic (CD34, CD45) and endothelial markers (CD31). They express human leukocyte antigen (HLA) class I but they are negative for HLA class II. MSCs can differentiate into skeletal, connective, and adipose tissue when exposed to proper conditions [3].

In the human BM, MSCs are localized around the blood vessels, where they offer physical support to HSPCs and differentiate into osteoprogenitors to guarantee a functional remodeling of the BM niche. Importantly, BM-MSCs control HSPC homeostasis by direct contact and in a paracrine manner 
through the secretion of soluble factors [4-6]. The concept that MSCs play a fundamental role in the regulation of hematopoiesis is supported by data showing the co-localization of MSCs with sites of hematopoiesis, starting from embryonic developmental stages [7]. The understanding of MSC's role in the BM niche has been limited for a long time due to the difficulty of identifying specific markers to localize and prospectively isolate MSCs in vivo. The lack of consensus on surface markers has generated contradictory results on independent subpopulations of MSCs [8-15]. However, recent studies have clarified the identity of MSC subsets which are mainly involved in the control of HSPC homeostasis. Sacchetti et al. first reported that MSCs positive for the CD146 marker reside in the sinusoidal wall, are enriched for colony forming unit-fibroblast (CFU-F) activity, and can generate a $\mathrm{BM}$ niche supporting hematopoietic activity when transplanted heterotopically in immunodeficient mice. CD146 ${ }^{+}$cells express HSPC regulatory genes such as Angiogenin- 1 and C-X-C motif chemokine 12 (CXCL12) [11]. Later, CD271 has been used to identify MSCs localized in the trabecular region of human BM. CD271 ${ }^{+}$MSCs show an enhanced clonogenic and differentiation capacity and express higher levels of extracellular matrix and cell adhesion genes compared to bulk MSCs [16-18]. These data suggest that different subtypes of MSCs interact with HSPCs in specific perivascular regions. $\mathrm{CD} 271^{+}$and $\mathrm{CD} 271^{+} / \mathrm{CD} 146^{-/ \text {low }}$ MSC have been reported to be bone-lining cells associated with long term (LT)-HSPC in low oxygen areas, whereas CD146 ${ }^{+}$and $\mathrm{CD} 271^{+} / \mathrm{CD} 146^{+}$are located around BM sinusoids in association with proliferating HSPCs [12] (Figure 1). Increasing evidence supports the hypothesis that MSCs represent a subpopulation of pericytes associated with the vessels of multiple human tissues. For this reason, MSCs/MSC-like cells have been isolated from several adult tissues, including adipose tissue, heart, skin, Wharton's jelly, dental pulp [19-21]. Despite the broad anatomical distribution, the majority of available data on MSC functionality have been obtained with ex-vivo expanded MSCs due to their low frequency. In human BM, MSCs represent $0.001-0.01 \%$ of mononuclear cells, thus requiring extensive ex-vivo manipulation for their functional characterization and clinical application [13]. Published data indicate that MSCs may become heterogeneous and acquire different properties upon plastic adherence and culture media exposure [22-24]. It has been shown that MSC cultures undergo clonal selection during the expansion phase, and selected clones possess different capabilities [25]. Moreover, MSC function is the result of coordinated interactions with the other BM niche components and may operate differently in vitro. Abbuehl et al. recently demonstrated that freshly-isolated murine BM-MSCs, but not ex-vivo expanded, are capable of engrafting long-term and to repair stromal niche damage after irradiation, translating into a significantly better HSPC engraftment after co-transplantation with HSPC intra-bone [26]. Genome-wide analysis has revealed a distinct transcriptional profile of human primary MSCs and corresponding in vitro counterpart, highlighting an enhanced hematopoietic supportive function in primary MSCs [22]. For this reason, the manipulation of culture conditions, including cytokines, glucose concentration, oxygen tension, culture as mesenspheres, have been proposed as a strategy to maintain MSC native properties [27-29], including their capacity to support HSPCs. More recently, the use of a cocktail of transcription factors has been shown to reprogram murine ex vivo expanded MSCs to a more primitive state [30].

MSCs have been employed as tools for tissue engineering and regenerative medicine [31-33], as well as a cell-therapy approach to counteract inflammation in immune-mediated and inflammatory diseases thanks to their capacity to sense the inflammatory state and suppressing immune responses [34-39]. Moreover, several pre-clinical and clinical studies have highlighted the role of ex-vivo cultured MSCs in promoting hematopoietic recovery and reducing the risk of graft failure $[40,41]$. MSCs have also been successfully employed to stimulate ex-vivo expansion and maintenance of CD34 ${ }^{+}$HSPCs [42,43].

Given their role in the BM niche and in HSPC support, dissecting the in vivo function of human MSCs and studying their properties in pathological conditions is a fundamental requirement to optimize the outcome of HSPC transplantation (HSCT) and ex-vivo HSPC-gene therapy (HSC-GT). As indicated in the editorial of the Special Issue "Mesenchymal Stromal Cell-Based Therapy: New Perspectives and Challenges" [44], also in the present review novel findings on the role of MSCs in the 
BM niche will be reported. In particular, alterations in the mesenchymal compartment in hematological malignancies, as well as in genetic disorders treated with HSCT or HSC-GT, will be discussed, focusing on the need to correct possible defects and preserve MSC functionality before transplantation.

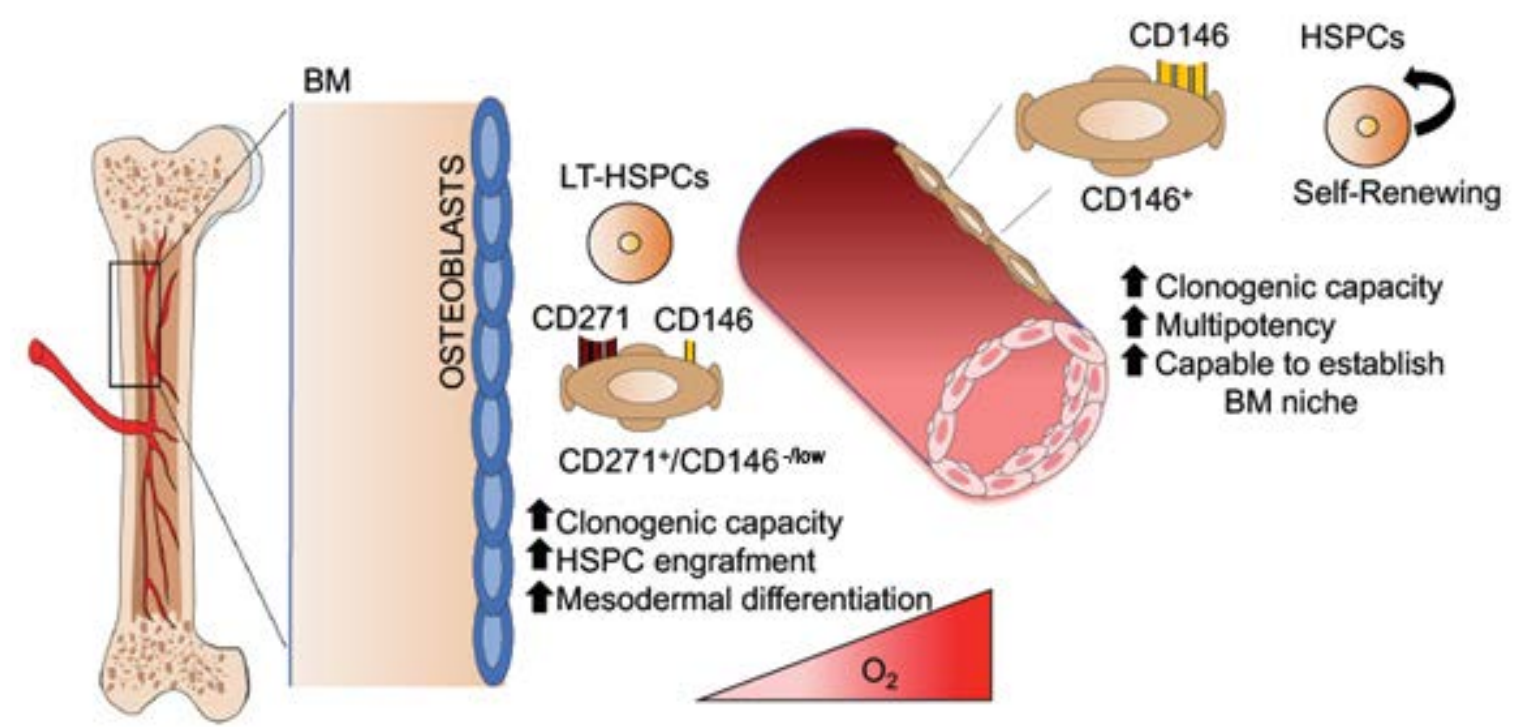

Figure 1. Schematic representation of a model describing mesenchymal stromal cells (MSCs) in the human bone marrow (BM) niche. In the human BM niche, different subtypes of MSCs interact with hematopoietic stem cells (HSCs) in the different perivascular regions and show specific functional characteristics. In particular, classification determinants (CD) 271 and CD $271^{+} / \mathrm{CD} 146^{-/ \mathrm{low}}$ MSCs are bone-lining MSCs associated with long-term (LT)-HSCs in low oxygen areas, whereas $\mathrm{CD}_{146^{+}}$and $\mathrm{CD} 271^{+} / \mathrm{CD} 146^{+}$are located around the BM sinusoids in association with activated and fast-proliferating HSCs. Abbreviations: BM-bone marrow; MSC-mesenchymal stromal cells; HSC—hematopoietic stem cell; CD—classification determinant; LT—long-term; HSPC—hematopoietic stem and progenitor cell.

\section{MSCs as Key Elements of the Bone Marrow Niche}

MSCs play a pivotal role in the control of hematopoiesis in the BM niche since the embryonal stage. MSCs have been identified in the aorta-gonad-mesonephros (AGM) region at E11, following the hematopoietic system development [7].

These cells have been extensively studied in vivo in several animal models, elucidating important aspects of MSC biological characteristics and function in the BM niche. In murine BM, MSCs occupy specific anatomic positions defined as endosteal and vascular niche [5,45]. In particular, MSCs localize in the endosteal niche, lining the bone surface and physically interacting with both osteoblasts and HSPCs $[6,46,47]$. Endosteal MSCs represent a source of osteoprogenitors and indirectly contribute to osteogenesis by secreting several growth factors and cytokines [48]. It has been shown that MSCs enhance bone regeneration [49] and mediate the capacity of parathyroid hormone to expand the osteoblast population, which, in turn, facilitates the expansion of primitive HSPCs through the secretion of several hematopoietic growth factors (granulocyte colony-forming factor, angiopoietin, interleukin 6 CXCL12) and the activation of Notch signaling [50,51].

In the vascular niche, MSCs are associated with blood vessels in a perivascular position, regulating HSPCs homeostasis by direct interaction with HSPCs or in a paracrine manner through the secretion of hematopoietic supportive factors [52,53]. Murine Nestin ${ }^{+}$MSCs have been first described as perivascular MSCs closely in contact with HSPCs. These cells are associated with blood vessels of the central marrow and are present at a lower frequency, in the endosteum. They are also in contact with adrenergic nerve fibers of the sympathetic nervous system, known to play an important role in 
regulating HSPC mobilization. Importantly, they express several HSPC maintenance factors, such as CXCL12, stem cell factor (SCF), angiopoietin-1, IL-7, vascular cell adhesion molecule 1 (VCAM1) [6,54].

Interestingly, Nestin ${ }^{+}$MSCs show several similarities to recently identified CXCL12-abundant reticular cells (CAR) [55]. CAR cells are also associated with sinusoidal endothelium; they have a morphology similar to vascular pericytes and sustain the maintenance of primitive HSPCs [56,57]. The reduction of the HSPC pool upon short-term ablation of CAR cells highlights the fundamental role of CAR cells in sustaining primitive HSPCs in a mouse model. In addition, the absence of CAR cells causes the upregulation of PU.1 in HSPCs and their commitment towards the myeloid lineage [58]. However, Nestin+ cells are considered a more primitive MSC population, since they are less abundant than CAR cells, show a higher clonogenic capacity, self-renewal activity, and differentiation potential [59]. These results sustain the concept of the BM stroma composed of different MSC subpopulations, localized in specific interconnected areas, which allows the crosstalk among different types of cells and molecular signaling.

Similarly, in the human BM niche, MSCs are localized in the endosteum and around the sinusoidal vessels [12]. Despite the study of the human BM niche, it is challenged by their difficult accessibility; different subpopulations of MSCs have been identified in vivo based on the expression of CD146 (MCAM), CD271 (Nerve Growth Factor Receptor), Stro-1, and stage-specific embryonic antigen-4 (SSEA-4) markers. CD271 is expressed by bone lining MSCs proximal to the surface of trabecular bone. $\mathrm{CD} 271^{+}$MSCs show a robust clonogenic capacity with an increased proliferation potential and ability to differentiate into mesodermal tissues compared to the CD271 negative MSCs [16]. Transcriptional analysis of $\mathrm{CD} 271^{+}$MSCs sorted from the BM confirmed enhanced expression of extracellular matrix and cell adhesion genes and increased levels of early osteogenesis/chondrogenesis/adipogenesis genes [18]. $\mathrm{CD} 271^{+}$MSCs have been shown to have enhanced capability in promoting HSPC engraftment [17]. However, the majority of CD271 ${ }^{+}$MSCs do not co-express CD90 and CD73, two of the markers included in the minimal criteria used to define ex-vivo expanded MSCs, according to the International Society for Cellular Therapy position paper [3]. For this reason, $\mathrm{CD} 271^{+}$expression is not an adequate marker to prospectively isolate bonafide MSCs from BM samples, although it is not clear whether the expression of CD90, CD73, and CD105 represents an in vitro artifact. Preliminary data obtained in our laboratory demonstrate the existence of a rare population of cells positive for CD90, CD73, CD105 in the CD34 negative fraction of BM aspirates. Moreover, CD271 shows different expression levels among various MSC subsets, and it is not universally expressed in MSCs derived from different tissues, suggesting that this marker is not sufficient to prospectively isolate MSCs [8,60]. For this reason, low/negative expression of PDGFR- $\alpha$ has been combined with CD271 expression to identify the candidate primary MSCs within the $\mathrm{CD} 45^{-} \mathrm{CD} 271^{+}$cell population [13]. CD146 ${ }^{+}$MSCs are localized around the sinusoidal vessels similar to pericytes, show high clonogenic capacity, and are able to re-establish the hematopoietic microenvironment when transplanted into xenograft models [11,61]. CD146 expression also defines MSCs with higher multipotency [62]. Importantly, CD146 expression differentiates between perivascular and endosteal localization of MSCs. Evidence to date suggests that $\mathrm{CD}_{271^{+}}$and $\mathrm{CD} 271^{+} / \mathrm{CD} 146^{-/ \text {low }}$ MSCs are bone-lining cells associated with long-term (LT)-HSPCs in low oxygen areas, whereas $\mathrm{CD} 146^{+}$and $\mathrm{CD} 271^{+} / \mathrm{CD} 146^{+}$are located around $\mathrm{BM}$ sinusoids in association with proliferating HSPCs. In both regions, HSPCs are located close to MSCs [12], which control their fate by secreting specific factors or by regulating the activity of the other niche components (Figure 1).

The use of Stro- 1 and SSEA-4 as MSC markers is more debated. Stro- 1 has been used in combination with negative selection for glycophorin-A to isolate highly clonogenic and multipotent MSCs from the BM [63]. However, in vivo studies demonstrated that Stro-1 negative MSCs support HSPCs engraftment in NOD/SCID mice [64]. SSEA-4 identifies a subpopulation of MSCs with high proliferation capacity, capable of differentiating into osteoblasts [65]. Nonetheless, other studies have demonstrated that SSEA-4 expression is an in vitro artifact due to serum exposure [66]. 
In light of these data, a deeper biological characterization of human BM-MSC subpopulations is required to better clarify their localization within the niche, the expression of specific surface markers for their prospective isolation, and their interaction with HSPCs. In this sense, the development of humanized niche models represents a powerful tool to dissect the hematopoietic supportive function of different MSC subpopulations in vivo within a microenvironment mimicking the human situation $[67,68]$.

\section{MSCs in the Clinical Use}

Thanks to their biological and functional properties, MSCs have emerged as a new therapeutic strategy for a wide range of clinical conditions. In particular, MSCs provide support to HSPCs in the BM niche and display potent inflammatory sensing capacities and immunomodulatory functions. Indeed, MSCs have been shown to interact and regulate the activity of innate and adaptive immune cells, despite several differences existing according to MSCs' tissue sources [69]. In particular, MSCs are able to inhibit B-, T-, and natural killer (NK)-cell proliferation by direct interaction and through the release of soluble molecules, such as transforming growth factor (TGF)- $\beta 1$ [70], indoleamine 2,3-dioxygenase (IDO) [71], prostaglandin E2 (PGE2) [72], which induces immune cells to arrest in G0, preventing their expansion. Besides, MSCs control T-cell activation inhibiting the production and secretion of inflammatory cytokines, and prevent the activation and maturation of dendritic cells [73]. Based on these properties, MSCs are considered an attractive "tool" to manage immune-mediated disorders, such as Graft-versus-Host-Disease (GvHD), a complication arising in patients undergoing allogeneic HSCT and associated with a high mortality rate. In 2004, Le Blanc first demonstrated in a seminal case report that the intravenous infusion of ex-vivo expanded BM-derived MSCs can effectively control manifestations of steroid-resistant, acute GvHD, in an allogeneic context. In the following Phase II trial, of the 55 patients treated with third-party donor MSCs for acute GvHD following allogeneic HSCT, 30 had a complete remission, and nine showed partial improvement. Indeed, these data demonstrate that MSCs might be a safe and effective treatment for patients suffering from acute GvHD who do not respond to standard immunosuppressive therapies [74]. Hereafter, other Phase II clinical trials have confirmed these results in terms of safety and efficacy of third-party donor MSC administration in the GvHD setting, suggesting that the timing of MSC infusions is critical to increasing their effectiveness and that the inflammatory state in the patients plays a fundamental role in the immunoregulatory activity of MSCs [75]. For these reasons, a precocious infusion after GvHD development and multiple administrations have been suggested as the best options for successful control of the disease [76]. Concerning chronic GvHD, the impact of MSC infusion is still debated, although combining MSCs and immunosuppressive therapies may be a safe and effective therapeutic option [77].

In addition to immunoregulatory functions, MSCs are known to promote and support HSPC engraftment. In vitro MSCs enhance the expansion and maintenance of HSPCs [78], whereas they promote long-term engraftment when co-transplanted with HSCPs in different animal models [79-81]. The molecular mechanism underlying the supportive effect of MSCs on HSC engraftment is still controversial. However, the capacity of MSCs to reduce inflammation in the BM niche and support HSPCs by secreting soluble factors render MSCs an attractive tool to ameliorate transplantation outcomes [82]. Indeed, conditioning regimens based on radiotherapy and chemotherapy administered before HSCT may profoundly affect the BM microenvironment, thus delaying hematopoietic reconstitution. MSCs have been co-infused with HSPCs in Phase I/II clinical trials with the aim of facilitating hematopoietic engraftment and reducing the risk of graft rejection, demonstrating its safety and efficacy $[41,82]$. Taking advantage of their hematopoietic supportive function, MSCs have been exploited to enhance HSPC expansion in vitro before HSCT with umbilical cord blood (UCB)-derived cells resulting in faster neutrophil and platelet recovery [42,43]. The use of MSCs is intended to mimic the stromal compartment of the BM niche by providing supportive factors for HSPC expansion and maintenance. Although MSCs have been demonstrated to preserve and support HSPC proliferation been through co-culture systems [42,83], differences may exist according to the 
source of MSCs. For example, placenta-derived MSCs have been reported to be a better feeder than UCB-derived MSCs, as they could maintain HSPCs in a more primitive state [84].

MSCs have also exploited clinically in the field of Regenerative Medicine, considering their ability to differentiate into bone and chondrocytes, especially when combined with biomaterial scaffolds. Scaffold employment and stimulating factors, such as BMP-2, are generally used to promote successful osteoblast differentiation for the regeneration of skeletal tissues [85]. Use of MSCs to repair damaged cartilage and other tissues, such as tendons, ligaments, and intervertebral discs, represents a novel and promising therapeutic strategy, especially for those tissues with avascular nature [86,87]. MSCs have been also employed for the regeneration of the central nervous system (CNS), heart and liver, cornea, and trachea [88]. In these cases, MSCs are thought to promote regeneration by secreting paracrine factors, despite there is no clear explanation. However, recent studies suggest that the main driving force behind the therapeutic efficacy of MSCs is the paracrine factors secreted by these cells and propose the administration of MSC-conditioned media for regenerative medicine applications [89]. In particular, MSCs have been demonstrated to provide beneficial effects in the treatment of neurological diseases, such as Parkinson [90], ischemic stroke [91], and multiple sclerosis [92]. Also, MSCs have been tested to promote- myocardium and liver regeneration.

In conclusion, MSCs are emerging as a promising strategy for cellular-based therapies in the context of inflammatory and immune-mediated diseases thanks to their ability to modulate inflammatory responses and immune cells. In the field of HSCT, MSCs have been extensively studied for their capacity to sustain HSPC and facilitate their engraftment. These properties have been exploited both in vitro in expansion strategies and in vivo in co-infusion approaches with the final goal to optimize HSCT outcome. Finally, the ability to differentiate and release growth factors in a damaged microenvironment render MSCs a valid tool for tissue regeneration. However, further pre-clinical studies and clinical trials are required to better elucidate the molecular mechanisms responsible for the therapeutic efficacy of MSCs. Furthermore, it must be taken into account that manufacturing MSCs in vitro, before administration, may affect some of their biological characteristics. The culture conditions should be refined and optimized to preserve primary MSC biological and functional properties and to minimize culture-induced alterations [93-95].

\section{MSCs in Hematological Malignancies}

In recent years an active role of the BM niche is emerging in the pathogenesis of human hematological malignancies. In particular, alterations in the mesenchymal compartment have been described to support the expansion and survival of leukemic stem cells (LSCs). The abnormal activity of MSCs is mainly caused by tumorigenic signals, which render the BM stroma immunologically tolerant to tumor growth and instruct MSCs to sustain LSCs at the expense of normal hematopoiesis. Several studies observed a reduced proliferative capacity of MSCs isolated from BM samples of patients affected by different hematological malignancies. In particular, it has been reported that MSCs derived from acute myeloid leukemia (AML) patients have a reduced capacity to form CFU-Fs, with a failure of $25 \%$ in MSCs isolation, and a lower population doubling compared to healthy controls [96]. AML-MSCs display an abnormal adipogenic potential [97], together with impaired osteogenic capacity and a diminished capacity to support CD $34^{+}$HSPCs [98]. In line with these observations, a genome-wide analysis of AML-MSCs confirmed reduced expression of hematopoietic supportive genes, including KIT ligand (KITLG), thrombopoietin (THPO), and angiopoietin (ANGPT1), associated with a reduced proliferation capacity and a perivascular signature of leukemic MSCs [99]. This defect was associated with an altered methylation profile of AML-MSCs, which impaired the expression of several genes fundamental in the BM niche. For instance, reduced expression of KITLG and overexpression of jagged canonical Notch ligand 1 (JAG1) in AML-MSCs was reported to favor $\mathrm{BM}$ niche support to LSCs. In particular, NOTCH/JAG1 signaling resulted in playing a fundamental role in MSC-dependent control of tumor initiation, growth, and chemoresistance. JAG1 overexpression has been shown to induce AML in mice [100], whereas NOTCH1, JAG1, and the main Notch target 
gene HES1 are overexpressed in AML-MSCs thus promoting survival of tumor cells exposed to chemotherapeutic agents [101] (Figure 2). Several studies have demonstrated that the tumor BM milieu is sufficient to convert a healthy BM stroma into a tumor supporting microenvironment. For example, the exposure of healthy donor MSCs to AML-MSC conditioned medium is sufficient to decrease MSC proliferation and osteogenic differentiation [98]. Other studies reported an increased immunosuppressive/anti-inflammatory potential in AML-MSCs compared to controls. In particular, IL-10 secretion by AML-MSCs resulted in correlating directly with overall patient survival $[102,103]$.

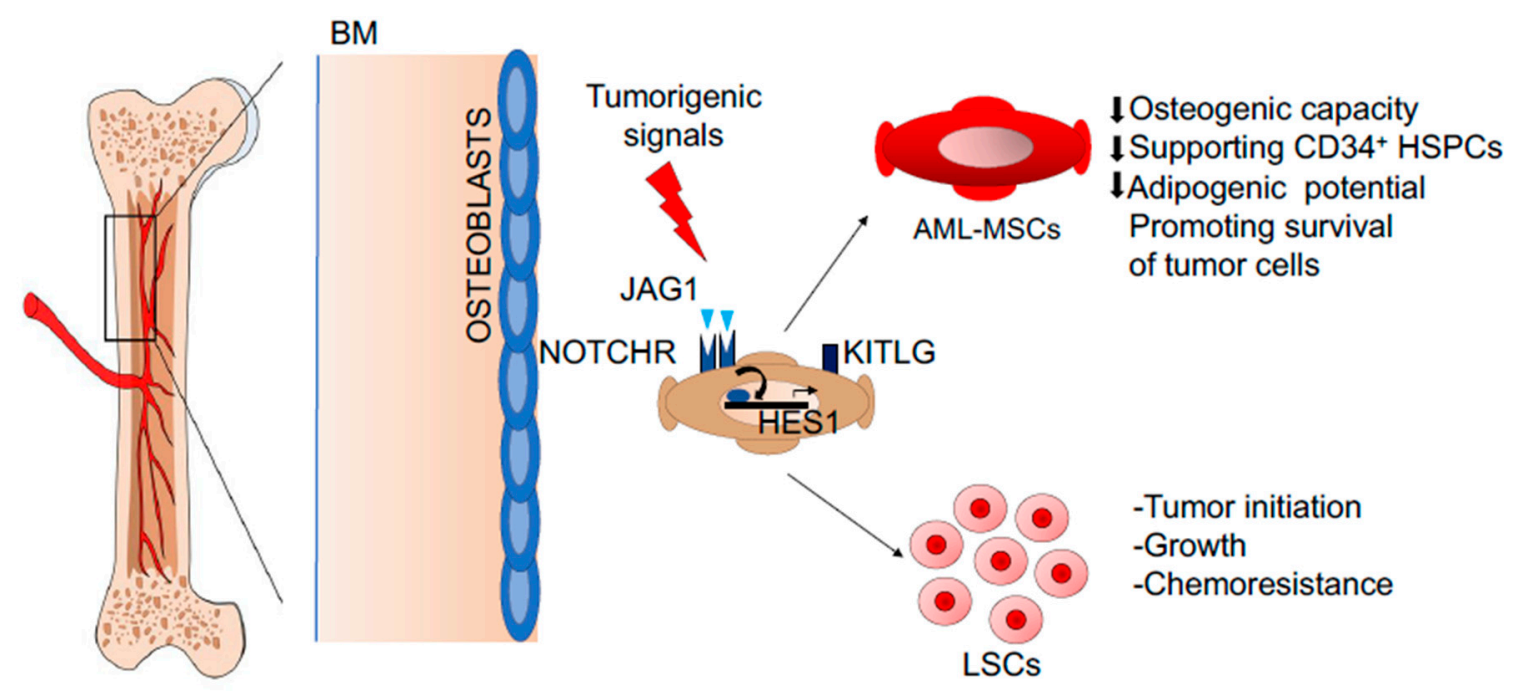

Figure 2. Representative image describing the role of the NOTCH/JAG1 pathway in AML-MSCs of a model describing MSCs in human BM niche. NOTCH/JAG1 signaling plays a fundamental role in the MSC-dependent control of tumor initiation, growth, and chemoresistance. NOTCH1, JAG1, and HES1 are overexpressed in AML-MSCs, promoting survival of tumor cells treated with chemotherapeutic agents. Abbreviations: NOTCH-Notch Homolog 1, Translocation-Associated; JAG1—of jagged canonical Notch ligand 1; AML-MSCs—acute myeloid leukemia derived mesenchymal stroma cells; MSC - mesenchymal stromal cells; BM-bone marrow; HES1—hairy and enhancer of split 1; KITLG—KIT ligand; LSCs_-leukemic stem cells; HSPCs—-hematopoietic stem and progenitor cells.

Similar to AML-MSCs, MSCs isolated from myelodysplastic (MDS) patients show a reduced proliferation rate [96]. Several pieces of evidence suggest a fundamental role of MSCs in the initiation of MDS in aged patients. Indeed, aged MSCs undergo replicative senescence and activate a specific senescence secretome in response to stress signals, including abnormal mitogenic signals, oxidative and genotoxic stress [104,105]. Among these secreted factors, several inflammatory cytokines sustain chronic inflammation, which could initiate and sustain cancer progression [106,107]. MDS-MSCs display in vitro several senescence features, including large, flat, and granular morphology, impaired proliferation, and increased $\beta$-galactosidase expression $[108,109]$. MSD-MSCs undergo premature cell-cycle arrest due to a significant upregulation of cyclin-dependent kinase inhibitor 2B (CDKN2B) compared to healthy counterparts, highlighting a possible role of MSCs in the control of tumor growth. Moreover, MDS-MSCs has been shown to support LSC expansion by different mechanisms specifically. These cells produce high levels of IL-6, which may modify HSPC biology. Indeed, from one side, IL-6 may induce HSPCs differentiation to the detriment of self-renewal, and, from the other side, it might increase LSC proliferation. Thus, MSCs, or better, dysfunctional MSCs, may affect cancer microenvironment [110]. Similarly, MDS cells proliferate to a greater extent on MDS-MSCs compared to normal MSCs. This is due to the downregulation of metalloproteinase 1 (MMP1), which renders MDS-MSCs unable to induce apoptosis in cancer cells [111]. Moreover, it has been shown that the expression of several hematopoietic supportive factors was reduced in MDS-MSCs, including KITLG and Angiopoietin-1. This results in a diminished cell cycle activity of HSPCs cultured on MDS-MSCs, 
highlighting that impaired stromal support contributes to ineffective hematopoiesis $[98,112,113]$. Moreover, several studies demonstrated an altered immunomodulatory function of MDS-MSCs, affecting tumor immune surveillance [114]. Evidence to date suggests that MSCs from neoplastic niche are educated to polarize macrophage toward an M2, anti-inflammatory, phenotype and they are responsible for increase Treg through the secretion of indoleamine 2,3-dioxygenase (IDO). In addition, MDS-MSCs have been shown to inhibit dendritic cell maturation and alter their functions, including endocytosis, IL-12 secretion, their ability to inhibit T cell proliferation. [115-117]. In this light, BM stroma contributes to the creation of a protective and immune-tolerant microenvironment capable of supporting the survival of leukemic cells and affect the response to therapies.

MSCs have also been isolated and characterized from BM samples of patients affected by acute lymphoblastic leukemia (ALL). ALL-MSCs isolated from children at different times in the course of the disease show reduced proliferation, increased adipogenic capacity, and impaired supportive function when co-cultured with HSPCs [118]. ALL-MSCs show a significantly higher level of pro-inflammatory cytokines, including IL-8 and CXCL2 [119], and express $\alpha$-smooth muscle actin, linked with cancer-associated fibroblasts that contribute to the acquisition of invasive phenotypes (CAFs) [120].

The dysregulation of BM stroma is mainly the result of extensive crosstalk between cancer cells and MSCs. However, a novel concept highlighting the primary role of MSCs in tumor initiation is emerging. In particular, it has been shown that primary stroma alterations can induce a malignant transformation of the hematopoietic compartment in different mouse models. In the first model, the deletion of Dicer1 in mouse osteoprogenitors impairs osteogenic differentiation and causes ineffective hematopoiesis with myelodysplasia [121]. Malignant cells acquire several genetic abnormalities while having intact Dicer1. Importantly, myelodysplasia is environmentally induced. When wild-type BM is transplanted into mutant mice or control mice, mutant recipients develop signs of myelodysplasia. Similarly, Dicer null osteoprogenitors induce abnormal modification of HSPCs in vitro. Dicer1 deletion is associated with reduced expression of the ribosome maturation factor Shwachman-Bodian-Diamond Syndrom (SBDS), encoded by the gene mutated in Schwachman-Bodian-Diamond syndrome, a human BM failure, and leukemia pre-disposition condition. Importantly, decreased expression of Dicer1 was detected in MSC-derived osteoprogenitors from myelodysplastic syndrome (MDS) patients, along with a reduction of the SBDS gene [122]. Similarly, conditional loss of nuclear factor kappa B (NFkB) inhibitor in stromal cells causes upregulation of JaG1/Notch signaling in HSPCs, resulting in a disorder similar to chronic myelomonocytic leukemia (CMML). On the contrary, constitutive activation of the NFkB pathway in myeloid cells does not recapitulate in a cell-autonomous manner the leukemia phenotype, clearly indicating that the malignant transformation of hematopoietic cells is initiated by BM stroma [123]. Increased expression of Notch1 and Jagged1 has been observed in cell lines from patients with AML [124]. Moreover, the deletion of the Retinoic Acid Receptor $\gamma$ (RAR $\gamma$ ) in mice resulted in a chronic myeloproliferative disorder. Transplant studies revealed that RAR $\gamma$-hematopoietic cells functioned normally when transplanted into normal mice. However, transplantation of normal hematopoietic cells into the RAR $\gamma$-microenvironment resulted in a myeloproliferative disorder in the transplanted cells, revealing the capability of the microenvironment to be the only cause of hematopoietic disorders [125]. Finally, the inactivation of the retinoblastoma (RB) gene in the hematopoietic system induces myeloproliferation, which is due to the mobilization and differentiation of HSPCs from the BM. HSPC homeostasis is preserved when mutated HSPCs are transplanted into wild-type recipients, highlighting an RB-dependent interaction between BM stroma and HSPCs as causative of malignant transformation. Importantly, a mutation in the retinoblastoma (RB) pathway has been described in a vast majority of multiple myeloma (MM) cases [126], which is the best-studied example demonstrating that the interaction of hematopoietic cells, in this case, B cells, and the BM microenvironment is a major contributor to disease $[127,128]$. In particular, myeloma cells directly interact with BM stroma or extracellular matrix through various adhesion molecules that lead to the activation of proliferation 
and anti-apoptotic pathways. On the other side, these interactions trigger the stromal compartment to release a variety of cytokines that support tumor cell growth.

In conclusion, MSCs represent a key component of the BM niche regulating HSPC homeostasis. Several works have described specific alterations of MSC functional characteristics in hematological malignancies that in the majority of the cases, are induced by tumor cells. Primary alterations in the BM stroma have also been described and demonstrated to be sufficient to initiate malignant transformation.

\section{Targeting BM Stroma: A Novel Therapeutic Approach to Treat Hematological Malignancies}

Considering the emerging active role of the BM microenvironment in the pathogenesis of hematological malignancies, the possibility to target the BM niche to contribute to the eradication of the disease has been evaluated in several clinical trials as an adjuvant treatment (Figure 3). One of the best representative cases is the use of Denosumab, a monoclonal antibody inhibiting receptor activator of nuclear factor-kappa-B ligand (RANKL) in multiple myeloma (MM) patients. RANKL expression is increased in MSCs of patients affected by MM, altering the normal balance of bone formation/reabsorption that is the cause of osteolytic lesions, bone pain, and related pathological fractures $[129,130]$. Several clinical trials demonstrated that Denosumab is capable of ameliorating bone disease in MM [131,132] and was associated with prolonged survival of treated patients, confirming an active role of BM stroma in the progression of the pathology [133]. The use of Dickkopf-related protein 1 (DKK-1) antagonist has been studied for their ability to restore osteoprogenitor function and prevent osteolytic bone lesions [134]. DKK1- plays an important role in MM-induced osteolysis by inhibiting osteoblast differentiation [135]. Besides, a key role of IGF1 in skeletal lesions formation has been described in MM patients [136]. The administration of small insulin growth factor-1 receptor (IGF-1R) inhibitors blocks the interaction of IGF1 released by BM stroma and tumor cells, causing a dose-dependent inhibition of cell proliferation and induction of cell death (Figure 3). Importantly, the altered balance of bone formation/bone resorption is not only the cause of bone lesions but also induces the release of proliferation/pro-survival factors from the BM stroma, which favor malignant cells at the dispense of HSPCs, favoring cancer progression [137]. For instance, the release of tumor necrosis factor- $\alpha$ (TNF- $\alpha)$ induces a change in the adhesion molecule profile of MM cells, which become more adherent to the BM niche displacing normal HSPCs [138]. This mechanism guarantees a higher level of protection from differentiation signaling and chemotherapeutic agents $[139,140]$. In this view, the VLA4-CD44 axes have been shown to increase the adhesion of cancer cells to MSCs and facilitate drug efflux [141]. Similarly, overexpression of $\mathrm{N}$-cadherin mediates the adhesion of malignant cells to MSCs by increasing the number of $\mathrm{N}$-cadherin- $\beta$-catenin complexes that promote the activation of Wnt signaling, mediating the resistance against tyrosine kinase [142]. An active form of TGF- $\beta$ is released upon bone remodeling, increasing the production of IL-6 in MSCs and tumor cells, which plays an essential role in promoting cancer progression $[143,144]$. The upregulation of C-X-C chemokine receptor type 4 (CXCR4) is another strategy adopted by cancer cells to find protection within the $\mathrm{BM}$ niche. Indeed, CXCR4-CXCL12 interaction is one of the best-studied players in the cross-talk between cancer cells and BM-MSCs. CXCR4 has been shown to be overexpressed in several types of hematological malignancies, conferring an increased capacity of LSCs to seed in the BM niche where the microenvironmental conditions are more conducive to cell proliferation and viability [145-147]. 


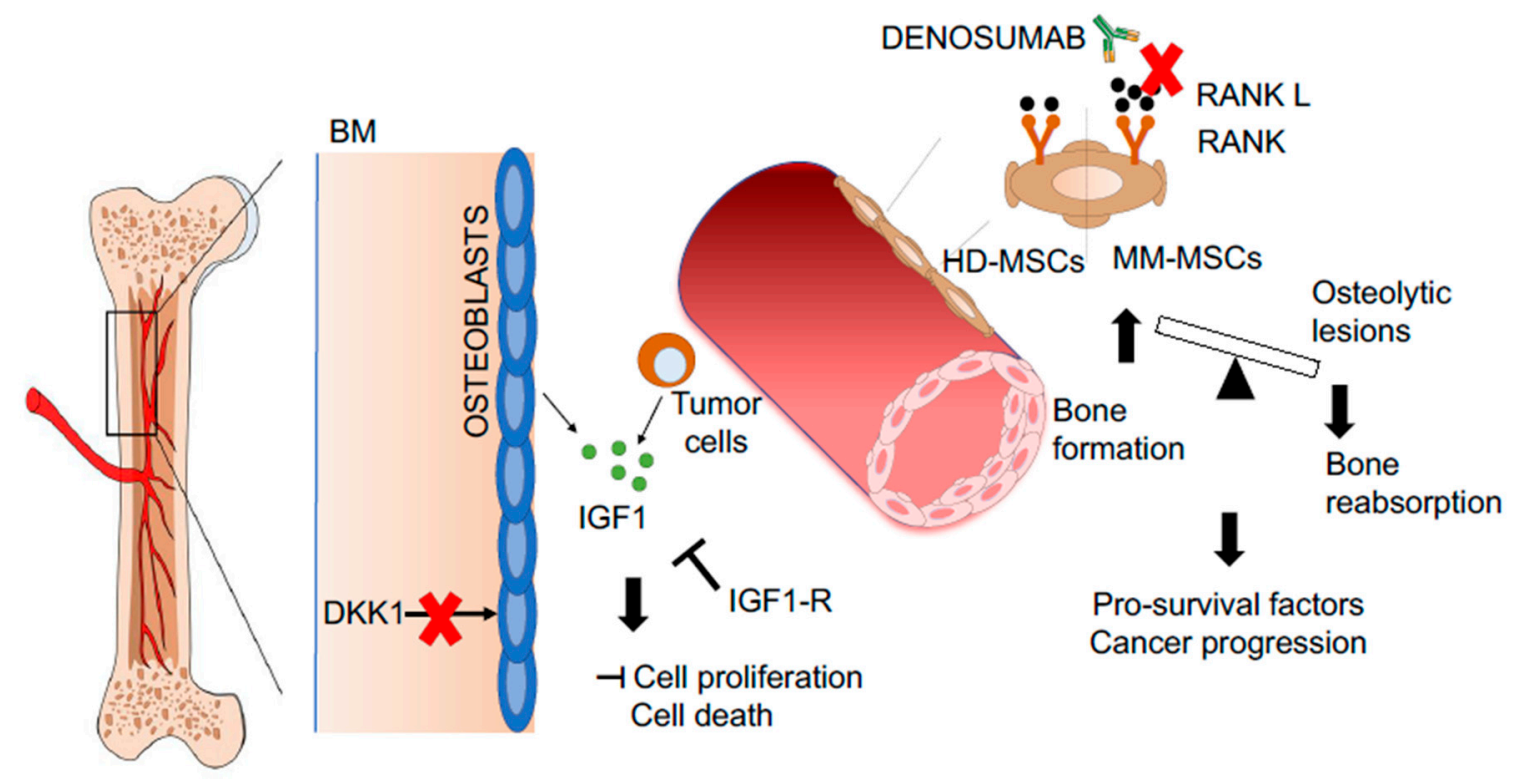

Figure 3. Representative pictures of novel therapeutic strategies targeting the malignant BM niche. Denosumab reduces osteolytic lesions by inhibiting the RANK-RANKL pathway (1). The mobilization of leukemic stem cells by plerixafor increase the efficacy of chemotherapy (2). Inhibition of DKK-1 prevents bone damage by inducing osteoblast differentiation (3). Inhibition of IGF1-R blocks the proliferation cascade activated by IGF1 released by osteoblast and tumor cells (4). Abbreviations: RANK-receptor activator of nuclear factor-kappa-B ligand; RANKL-RANK ligand; DKK-1—Dickkopf-related protein 1; IGF1-insulin growth factor 1; IGF1-R-IGF1 receptor; BM-bone marrow; HD-MSCs—healthy donor-derived mesenchymal stromal cells; MM-MSCs—-multiple myeloma-derived mesenchymal stromal cells.

Therefore, there are several levels of intervention to modulate the interaction of tumor cells with the BM stroma and reach a therapeutic effect. For instance, blocking CXCL12 binding to CXCR4 with the use of plerixafor (AMD3100) renders MM cells more susceptible to chemotherapeutic drugs through their mobilization into the circulation [148]. Similarly, several monoclonal antibodies against cell adhesion molecules (such as integrins) have been successfully evaluated pre-clinically to mobilize malignant cells from the BM [149]. Several drugs have been developed to neutralize the effect of IL-6 [150]. Conventional agents, such as INF- $\gamma$ and all-trans retinoic acid (ATRA), has been shown to inhibit MM cell growth [151,152]. More recently, histone deacetylase (HDAC) inhibitors have been used to suppress the stromal production of IL-6 in co-culture models of MM cells and BM-derived MSCs [153,154].

Overall, these results support the central role of the BM stroma in the pathogenesis and progression of cancer. Considering that HSCT is curative in many of the disorders under discussion, a proper correction of tumor BM stroma is emerging as a strategy to ameliorate transplantation outcomes. Indeed, stromal cells remain of host origin after transplantation [155]. There have been reports of patients who are unable to achieve engraftment despite numerous attempts at HSCT [156], as well as cases in which leukemia arises after transplantation in donor cells [157-159] and one may speculate that these patients represent groups that do indeed have an underlying stromal defect which may benefit from targeted correction.

\section{MSCs in Rare Genetic Diseases}

The concept of a properly functional BM niche as a key requirement for the outcome of HSPC transplantation could be extended to all those diseases for which this procedure is indicated as a curative option, including a wide variety of rare genetic diseases, ranging from defects in the immune system, HSPC functionality, or metabolic diseases. In this sense, profound knowledge of BM stroma 
biology is fundamental for the optimization of transplantation strategies, especially in the context of HSC-GT, where the relationship between HSPCs and the stroma may influence harvest and behavior in culture, as well as HSC engraftment kinetics after gene modification. Indeed, the functionality of HSPC could be affected by the diseased microenvironment, and, on the other side, the diseased niche could have a reduced capacity to sustain the engraftment of gene-corrected HSPCs [160-163].

In support of this hypothesis, different studies have highlighted specific alterations in the MSCs isolated from the BM samples of patients affected by genetic disorders that are treated with (hematopoietic stem progenitor cell transplantation (HSPCT) or HSC-GT. These results evidence the need for novel strategies to correct the BM niche before or during transplantation and the development of biological conditioning to avoid further damage of the BM stroma to improve transplantation protocols, by sparing their supporting niche $[164,165]$. In particular, MSCs have been isolated and characterized from pediatric patients affected by primary immune-deficiencies (PIDs) and undergoing HSCT or HSC-GT. Despite the fact that primary immunodeficiencies-mesenchymal stromal cells (PID-MSCs) do not display any alterations in terms of proliferation, differentiation, expression of MSC surface markers, the immunomodulatory capacity of PID-MSCs is altered compared to age-matched controls $[166,167]$. In particular, MSCs isolated from ADA-SCID, Wiskott-Aldrich Syndrome, Chronic Granulomatous Disease, and other SCID patients showed decreased inhibitory effect on T-cell proliferation. This is accompanied by a dysregulated production of pro- and anti-inflammatory cytokines. Alterations have also been observed in B-cell inhibition and maturation in the presence of PID-MSCs. On the other hand, priming of PID-MSCs with Toll-like receptor (TLR)3 and TLR4 evidence defects in the production of immunoregulatory molecules [167]. These data highlight defects in the immunoregulatory properties of PID-MSCs, which may be exhausted due to frequent, ongoing infections and extensive inflammation characteristic of PID patients (Figure 4). Importantly, from a clinical view, the altered secretory profile of PID-MSCs could impair their capacity to support gene-corrected HSPCs after gene therapy (GT). Indeed, a decreased functional activity and tendency to differentiation and exhaustion of HSPCs have been demonstrated in CGD patients [168].
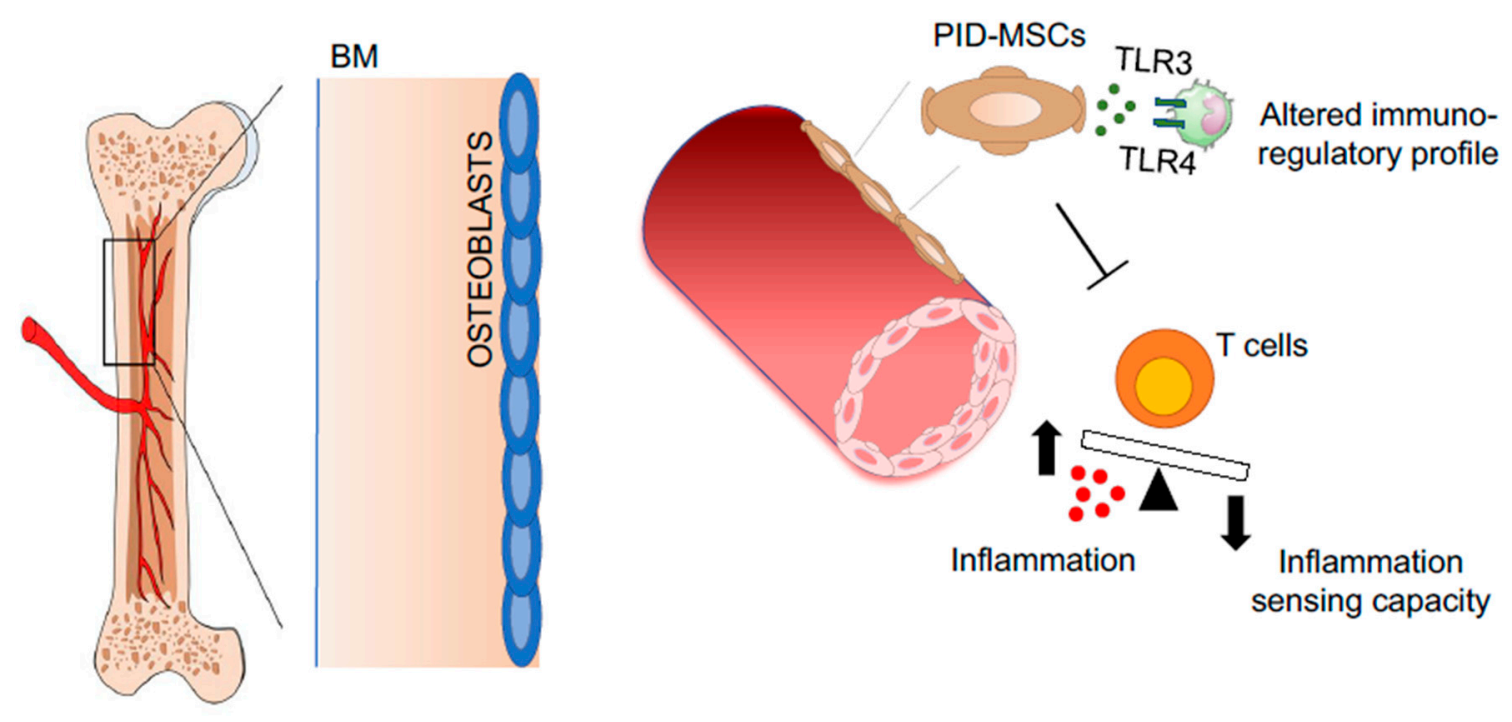

Figure 4. Representative pictures of pathological BM niches in PIDs. MSCs derived from primary immune-deficient (PIDs) patients, suffering from frequent infection and extensive inflammation, which compromises the capacity of MSCs to control T cell proliferation and alters their immunoregulatory profile. Abbreviations: BM—bone marrow; PID—primary immunodeficiencies; MSCs—mesenchymal stromal cells; TLR-Toll-like receptor.

MSCs have also been isolated from the BM aspirates of Mucopolysaccharidosis type I Hurler (MPSIH) patients, where the intracellular accumulation of glycosaminoglycans (GAGs) causes 
multiorgan dysfunction, including skeletal defects [169]. Considering the fundamental role of bone remodeling in support of HSPC homeostasis [5], the capability of MPSIH-MSCs to differentiate into functional osteoblasts has been evaluated in vitro and in vivo. Although MPSIH-MSCs can differentiate into osteoblasts, an unbalanced bone remodeling status has been noticed; indeed, an upregulation of RANKL/RANK/OPG (osteoprotegerin) has been found in patient-derived MSCs compared to controls, indicating increased ability to support osteoclastogenesis [170] (Figure 5). An extensive characterization of HSPCs in MPSIH patients is missing and may highlight possible defects in HSPC homeostasis, taking into consideration that osteoclasts play a fundamental role in HSPC mobilization and other functions [171-173]. An important aspect to be considered is that the extensive ex vivo culture of MPSIH-MSCs may change their functional characteristics, reducing the extent of the functional defects [30]. The culture of MSCs in conditions of glycosaminoglycans (GAGs) overload may represent a valid strategy to reproduce in vitro the pathological conditions of the MPSIH BM niche. Following this hypothesis, MSCs isolated from BM samples of transfusion-dependent $\beta$-thalassemia (BT) patients have been exposed in vitro to iron to study their antioxidant response in a condition mimicking the iron overload state of the BM niche. BT-MSCs show an impaired clonogenic capacity, reduced proliferation rate, and altered differentiation potential. A condition of iron overload has been identified in the BM niche of BT patients causing a significant upregulation of ROS level in BT-MSCs. The exposure of BT-MSCs to increasing doses of iron revealed an inappropriate antioxidant response, which is responsible for the pauperization of the most primitive MSC fraction [174]. In addition, $\beta$-thalassemia-mesenchymal stromal cells (BT-MSCs) express lower level of hematopoietic supportive factors compared to controls, that negatively affect their ability to attract HSPCs in vitro, to sustain HSPC expansion and primitive phenotype in 2D co-culture model, to favor HSPC engraftment and immunological reconstitution in xenogenic transplant models, and to form a proper BM niche in vivo [174] (Figure 6). These results highlight a profound defect in the BM niche of BT patients, which may explain the increased risk of graft rejection and mixed chimerism observed after HSTC $[175,176]$ and prove the need to treat the BM niche with the aim of reducing oxidative stress, thus potentially ameliorating transplantation outcome.

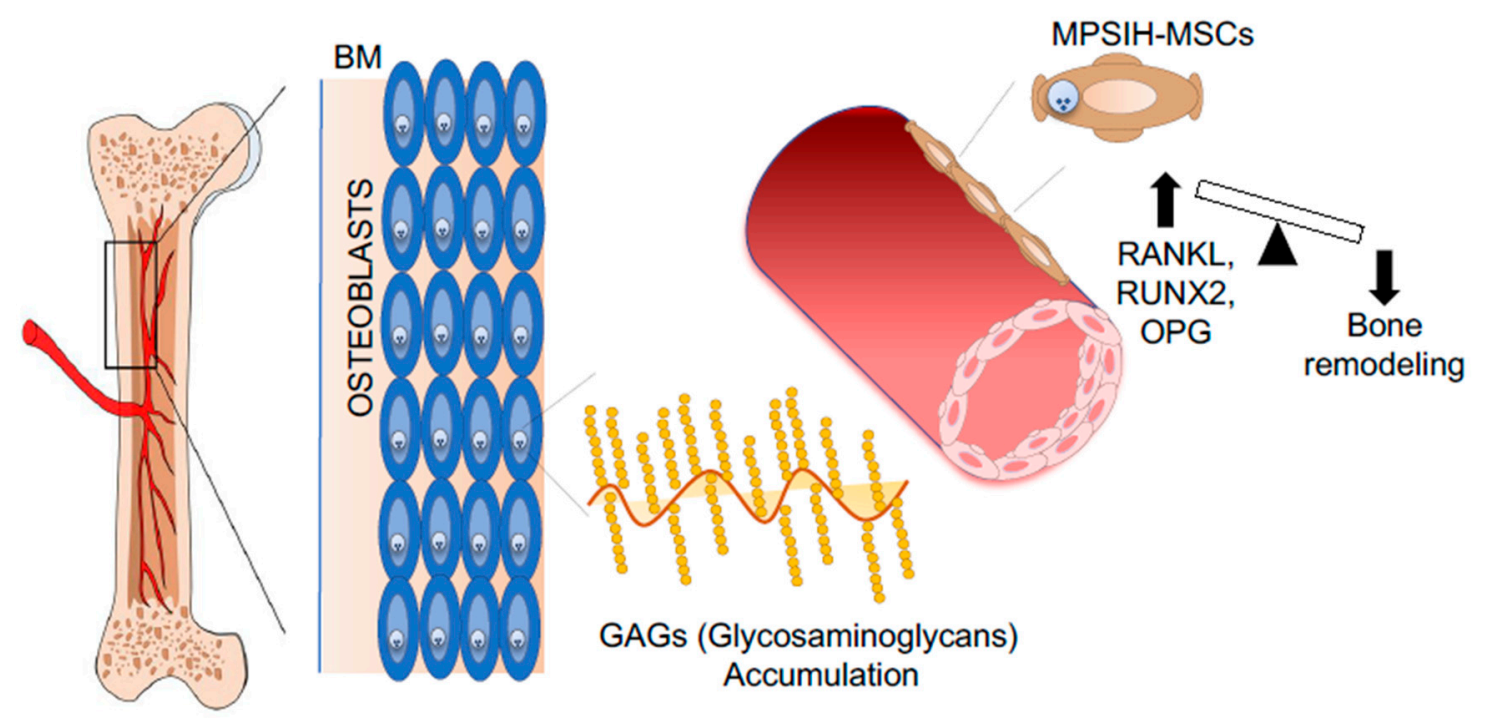

Figure 5. Representative pictures of pathological BM niches in MPSIH patients. MSCs derived from mucopolysaccharidosis type I- Hurler-syndrome (MPSIH) patients. The accumulation of Glycosaminoglycans (GAGs) causes multiorgan dysfunction, including bone defects. The upregulation of RANKL/RANK/OPG pathway causes unbalanced bone remodeling. Abbreviations: BM-bone marrow; MPSIH-MSCs-Mucopolysaccharidosis type I Hurler-derived mesenchymal stroma cells; RANK-receptor activator of nuclear factor-kappa-B ligand; RANKL-RANK ligand; OPG-osteoprotegerin. 


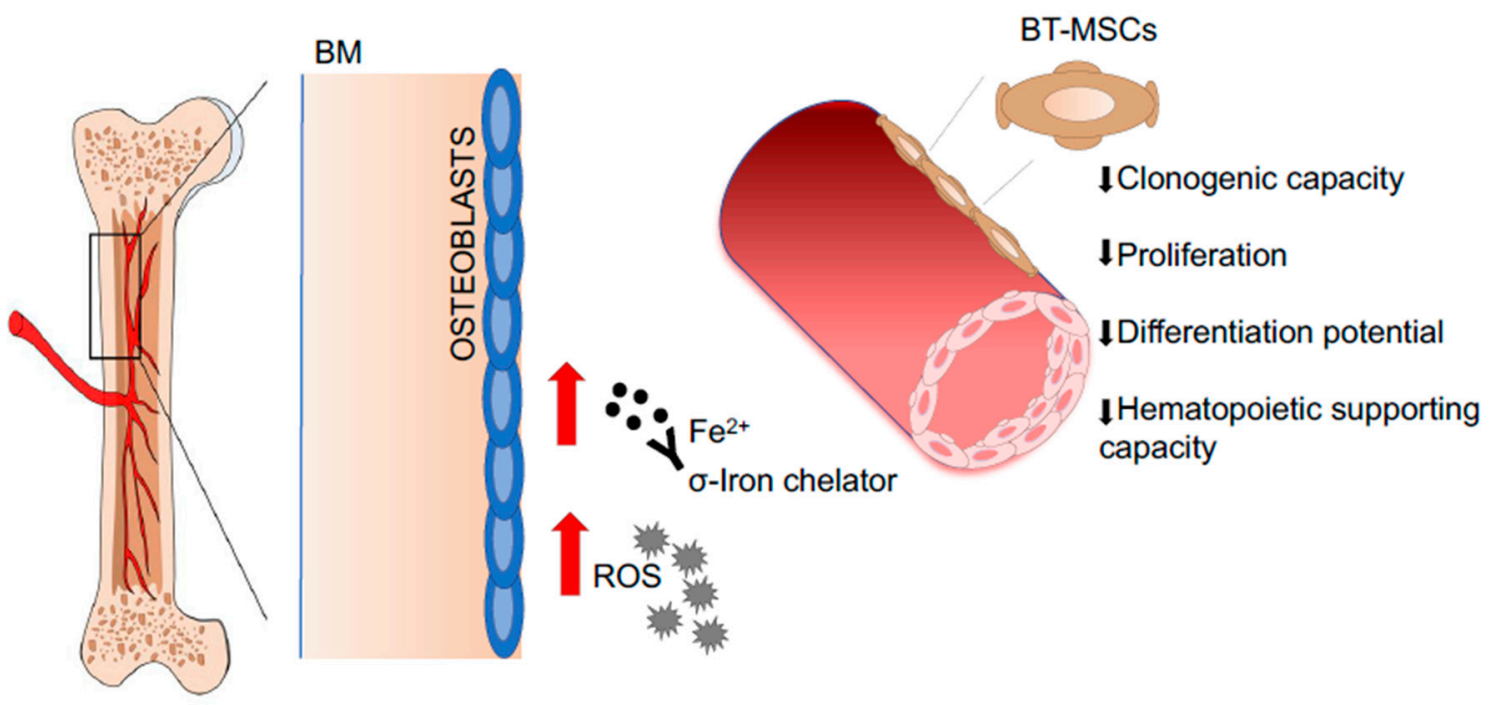

Figure 6. Representative pictures of pathological BM niches in BT patients. MSCs derived from Beta Thalassemia (BT) patients. Iron accumulation in the BM leads to increased levels of Radical Oxygen Species (ROS), which causes a pauperization of the primitive MSC pool and alters the MSC hematopoietic supportive function. Abbreviations: BM-bone marrow; BT-MSCs—beta-thalassemia derived mesenchymal stroma cells; $\mathrm{Fe}^{2+}$-iron, ferrous ion.

In light of these studies, the use of MSCs in co-transplantation strategies in the clinical setting to facilitate the engraftment of HSPCs $[41,177]$ and to promote the rescue of the resident stromal compartment may be evaluated in some pathologies. Indeed, considering the disease-specific defects observed in patient-derived MSCs, co-administration of third-party, healthy donor-derived MSCs is to be preferred in co-transplantation settings [178]. In conclusion, recent data show specific alterations in the mesenchymal compartment of patients affected by rare genetic disorders and evidence the need to investigate the functional properties of diseased MSCs, to restore a proper microenvironment supporting HSPC engraftment and long-term hematopoiesis, with the final goal to improve the efficacy of HSC transplantation.

\section{Conclusions}

HSCT is an available curative option for several hematological malignant and nonmalignant disorders, including genetic diseases. A proper functional bone marrow niche is a fundamental requirement to guarantee an efficient HSC engraftment and hematological reconstitution. The co-infusion of MSCs has emerged as a feasible and safe therapeutic strategy to improve the HSCT outcome. Indeed, MSCs have been shown to support the engraftment of transplanted HSCs reducing the risk of graft failure by secreting soluble factors, and limiting the risk of GvHD thanks to their anti-inflammatory properties. However, several alterations of the stromal compartment have been described in malignant and nonmalignant diseases, which compromises MSC biological characteristics and hematopoietic supportive capacity. These findings have important implications for the clinical practice of HSCT. First, they suggest that BM stromal compartment associated defects may contribute to the reduced HSC engraftment leading to graft failure in some specific diseases, such as beta-thalassemia or other hematological disorders. Moreover, considering that the BM stroma plays a central role in the control of HSC homeostasis, the altered functionality of MSCs may negatively affect the hematopoietic dynamics of HSCPs following transplantation. Several cases also report that BM stroma contributes to hematological disease-relapse in donor cells after transplantation for malignant disorders by modifying the BM microenvironment in support of tumor cells. All these observations highlight the need to deeply study the BM microenvironment with the aim to restore the proper signaling to support HSPC engraftment and long-term hematopoiesis, improving the efficacy of HSC transplantation. 
Furthermore, considering the impaired function of MSCs in some specific diseased contexts, the co-administration of allogeneic, HD-derived MSCs is to be preferred in co-transplantation settings with the aim to ameliorate HSC engraftment in patients.

Author Contributions: S.C. conceptualized the paper, analyzed data and wrote the paper, L.S., R.B. and G.P. took care of the original draft preparation, R.B. prepared the figures; M.E.B. reviewed and edited the paper. All authors have read and agreed to the published version of the manuscript.

Funding: This research was funded by the SR-Tiget Core Grant (E6) from Fondazione Telethon to MEB.

Conflicts of Interest: The authors declare no conflict of interest.

\section{References}

1. Friedenstein, A.J.; Chailakhjan, R.K.; Lalykina, K.S. The development of fibroblast colonies in monolayer cultures of guinea-pig bone marrow and spleen cells. Cell Tissue Kinet 1970, 3, 393-403. [CrossRef] [PubMed]

2. Caplan, A.I. Mesenchymal stem cells. J. Orthop. Res. 1991, 9, 641-650. [CrossRef] [PubMed]

3. Dominici, M.; Le Blanc, K.; Mueller, I.; Slaper-Cortenbach, I.; Marini, F.; Krause, D.; Deans, R.; Keating, A.; Prockop, D.J.; Horwitz, E. Minimal criteria for defining multipotent mesenchymal stromal cells. The International Society for Cellular Therapy position statement. Cytotherapy 2006, 8, 315-317. [CrossRef] [PubMed]

4. Crane, G.M.; Jeffery, E.; Morrison, S.J. Adult haematopoietic stem cell niches. Nat. Rev. Immunol. 2017, 17, 573-590. [PubMed]

5. Morrison, S.J.; Scadden, D.T. The bone marrow niche for haematopoietic stem cells. Nature 2014, 505, 327-334. [CrossRef] [PubMed]

6. Mendez-Ferrer, S.; Michurina, T.V.; Ferraro, F.; Mazloom, A.R.; Macarthur, B.D.; Lira, S.A.; Scadden, D.T.; Ma'ayan, A.; Enikolopov, G.N.; Frenette, P.S. Mesenchymal and haematopoietic stem cells form a unique bone marrow niche. Nature 2010, 466, 829-834. [CrossRef]

7. Mendes, S.C.; Robin, C.; Dzierzak, E. Mesenchymal progenitor cells localize within hematopoietic sites throughout ontogeny. Development 2005, 132, 1127-1136. [CrossRef]

8. Quirici, N.; Soligo, D.; Bossolasco, P.; Servida, F.; Lumini, C.; Deliliers, G.L. Isolation of bone marrow mesenchymal stem cells by anti-nerve growth factor receptor antibodies. Exp. Hematol. 2002, 30, 783-791. [CrossRef]

9. Churchman, S.M.; Ponchel, F.; Boxall, S.A.; Cuthbert, R.; Kouroupis, D.; Roshdy, T.; Giannoudis, P.V.; Emery, P.; McGonagle, D.; Jones, E.A. Transcriptional profile of native CD271+ multipotential stromal cells: Evidence for multiple fates, with prominent osteogenic and Wnt pathway signaling activity. Arthritis Rheum. 2012, 64, 2632-2643. [CrossRef]

10. Battula, V.L.; Treml, S.; Bareiss, P.M.; Gieseke, F.; Roelofs, H.; de Zwart, P.; Muller, I.; Schewe, B.; Skutella, T.; Fibbe, W.E.; et al. Isolation of functionally distinct mesenchymal stem cell subsets using antibodies against CD56, CD271, and mesenchymal stem cell antigen-1. Haematologica 2009, 94, 173-184. [CrossRef]

11. Sacchetti, B.; Funari, A.; Michienzi, S.; Di Cesare, S.; Piersanti, S.; Saggio, I.; Tagliafico, E.; Ferrari, S.; Robey, P.G.; Riminucci, M.; et al. Self-renewing osteoprogenitors in bone marrow sinusoids can organize a hematopoietic microenvironment. Cell 2007, 131, 324-336. [CrossRef] [PubMed]

12. Tormin, A.; Li, O.; Brune, J.C.; Walsh, S.; Schutz, B.; Ehinger, M.; Ditzel, N.; Kassem, M.; Scheding, S. CD146 expression on primary nonhematopoietic bone marrow stem cells is correlated with in situ localization. Blood 2011, 117, 5067-5077. [CrossRef] [PubMed]

13. Li, H.; Ghazanfari, R.; Zacharaki, D.; Ditzel, N.; Isern, J.; Ekblom, M.; Mendez-Ferrer, S.; Kassem, M.; Scheding, S. Low/negative expression of PDGFR-alpha identifies the candidate primary mesenchymal stromal cells in adult human bone marrow. Stem Cell Rep. 2014, 3, 965-974. [CrossRef] [PubMed]

14. Mabuchi, Y.; Morikawa, S.; Harada, S.; Niibe, K.; Suzuki, S.; Renault-Mihara, F.; Houlihan, D.D.; Akazawa, C.; Okano, H.; Matsuzaki, Y. LNGFR(+)THY-1(+)VCAM-1(hi+) cells reveal functionally distinct subpopulations in mesenchymal stem cells. Stem Cell Rep. 2013, 1, 152-165. [CrossRef]

15. Pinho, S.; Lacombe, J.; Hanoun, M.; Mizoguchi, T.; Bruns, I.; Kunisaki, Y.; Frenette, P.S. PDGFRalpha and CD51 mark human nestin+ sphere-forming mesenchymal stem cells capable of hematopoietic progenitor cell expansion. J. Exp. Med. 2013, 210, 1351-1367. [CrossRef] 
16. Jones, E.A.; Kinsey, S.E.; English, A.; Jones, R.A.; Straszynski, L.; Meredith, D.M.; Markham, A.F.; Jack, A.; Emery, P.; McGonagle, D. Isolation and characterization of bone marrow multipotential mesenchymal progenitor cells. Arthritis Rheum. 2002, 46, 3349-3360. [CrossRef]

17. Kuci, S.; Kuci, Z.; Kreyenberg, H.; Deak, E.; Putsch, K.; Huenecke, S.; Amara, C.; Koller, S.; Rettinger, E.; Grez, M.; et al. CD271 antigen defines a subset of multipotent stromal cells with immunosuppressive and lymphohematopoietic engraftment-promoting properties. Haematologica 2010, 95, 651-659. [CrossRef]

18. Ganguly, P.; El-Jawhari, J.J.; Burska, A.N.; Ponchel, F.; Giannoudis, P.V.; Jones, E.A. The analysis of in vivo aging in human bone marrow mesenchymal stromal cells using colony-forming unit-fibroblast assay and the CD45(low)CD271(+) phenotype. Stem Cells Int. 2019, 2019, 5197983. [CrossRef]

19. Secunda, R.; Vennila, R.; Mohanashankar, A.M.; Rajasundari, M.; Jeswanth, S.; Surendran, R. Isolation, expansion and characterisation of mesenchymal stem cells from human bone marrow, adipose tissue, umbilical cord blood and matrix: A comparative study. Cytotechnology 2015, 67, 793-807. [CrossRef]

20. Beeravolu, N.; McKee, C.; Alamri, A.; Mikhael, S.; Brown, C.; Perez-Cruet, M.; Chaudhry, G.R. Isolation and characterization of mesenchymal stromal cells from human umbilical cord and fetal placenta. J. Vis. Exp. 2017, 122, e55224. [CrossRef]

21. Arana, M.; Mazo, M.; Aranda, P.; Pelacho, B.; Prosper, F. Adipose tissue-derived mesenchymal stem cells: Isolation, expansion, and characterization. Methods Mol. Biol. 2013, 1036, 47-61. [PubMed]

22. Ghazanfari, R.; Zacharaki, D.; Li, H.; Ching Lim, H.; Soneji, S.; Scheding, S. Human primary bone marrow mesenchymal stromal cells and their in vitro progenies display distinct transcriptional profile signatures. Sci. Rep. 2017, 7, 10338. [CrossRef] [PubMed]

23. Mosna, F.; Sensebe, L.; Krampera, M. Human bone marrow and adipose tissue mesenchymal stem cells: A user's guide. Stem Cells Dev. 2010, 19, 1449-1470. [CrossRef] [PubMed]

24. Colter, D.C.; Sekiya, I.; Prockop, D.J. Identification of a subpopulation of rapidly self-renewing and multipotential adult stem cells in colonies of human marrow stromal cells. Proc. Natl. Acad. Sci. USA 2001, 98, 7841-7845. [CrossRef] [PubMed]

25. Selich, A.; Ha, T.C.; Morgan, M.; Falk, C.S.; von Kaisenberg, C.; Schambach, A.; Rothe, M. Cytokine selection of MSC clones with different functionality. Stem Cell Rep. 2019, 13, 262-273. [CrossRef]

26. Abbuehl, J.P.; Tatarova, Z.; Held, W.; Huelsken, J. Long-term engraftment of primary bone marrow stromal cells repairs niche damage and improves hematopoietic stem cell transplantation. Cell Stem Cell 2017, 21, 241-255. [CrossRef]

27. Zhou, Y.; Tsai, T.L.; Li, W.J. Strategies to retain properties of bone marrow-derived mesenchymal stem cells ex vivo. Ann. N. Y. Acad. Sci. 2017, 1409, 3-17. [CrossRef]

28. Li, Y.M.; Schilling, T.; Benisch, P.; Zeck, S.; Meissner-Weigl, J.; Schneider, D.; Limbert, C.; Seufert, J.; Kassem, M.; Schutze, N.; et al. Effects of high glucose on mesenchymal stem cell proliferation and differentiation. Biochem. Biophys Res. Commun. 2007, 363, 209-215. [CrossRef]

29. Lv, H.; Li, L.; Sun, M.; Zhang, Y.; Chen, L.; Rong, Y.; Li, Y. Mechanism of regulation of stem cell differentiation by matrix stiffness. Stem Cell Res. Ther. 2015, 6, 103. [CrossRef]

30. Nakahara, F.; Borger, D.K.; Wei, Q.; Pinho, S.; Maryanovich, M.; Zahalka, A.H.; Suzuki, M.; Cruz, C.D.; Wang, Z.; Xu, C.; et al. Engineering a haematopoietic stem cell niche by revitalizing mesenchymal stromal cells. Nat. Cell Biol. 2019, 21, 560-567. [CrossRef]

31. Rohban, R.; Pieber, T.R. Mesenchymal stem and progenitor cells in regeneration: Tissue specificity and regenerative potential. Stem Cells Int. 2017, 2017, 5173732. [CrossRef] [PubMed]

32. Steinert, A.F.; Rackwitz, L.; Gilbert, F.; Noth, U.; Tuan, R.S. Concise review: The clinical application of mesenchymal stem cells for musculoskeletal regeneration: Current status and perspectives. Stem Cells Transl. Med. 2012, 1, 237-247. [CrossRef] [PubMed]

33. Martin, I.; Galipeau, J.; Kessler, C.; le Blanc, K.; Dazzi, F. Challenges for mesenchymal stromal cell therapies. Sci. Transl. Med. 2019, 11, eaat2189. [CrossRef] [PubMed]

34. le Blanc, K.; Davies, L.C. Mesenchymal stromal cells and the innate immune response. Immunol. Lett. 2015, 168, 140-146. [CrossRef] [PubMed]

35. Nauta, A.J.; Fibbe, W.E. Immunomodulatory properties of mesenchymal stromal cells. Blood 2007, 110, 3499-3506. [CrossRef] [PubMed]

36. Bernardo, M.E.; Fibbe, W.E. Mesenchymal stromal cells: Sensors and switchers of inflammation. Cell Stem Cell 2013, 13, 392-402. [CrossRef] 
37. Krampera, M. Mesenchymal stromal cell 'licensing': A multistep process. Leukemia 2011, 25, 1408-1414. [CrossRef] [PubMed]

38. Stagg, J.; Galipeau, J. Mechanisms of immune modulation by mesenchymal stromal cells and clinical translation. Curr. Mol. Med. 2013, 13, 856-867. [CrossRef]

39. Galleu, A.; Riffo-Vasquez, Y.; Trento, C.; Lomas, C.; Dolcetti, L.; Cheung, T.S.; von Bonin, M.; Barbieri, L.; Halai, K.; Ward, S.; et al. Apoptosis in mesenchymal stromal cells induces in vivo recipient-mediated immunomodulation. Sci. Transl. Med. 2017, 9, eaam7828. [CrossRef]

40. Bernardo, M.E.; Ball, L.M.; Cometa, A.M.; Roelofs, H.; Zecca, M.; Avanzini, M.A.; Bertaina, A.; Vinti, L.; Lankester, A.; Maccario, R.; et al. Co-infusion of ex vivo-expanded, parental MSCs prevents life-threatening acute GVHD, but does not reduce the risk of graft failure in pediatric patients undergoing allogeneic umbilical cord blood transplantation. Bone Marrow Transplant. 2011, 46, 200-207. [CrossRef]

41. Ball, L.M.; Bernardo, M.E.; Roelofs, H.; Lankester, A.; Cometa, A.; Egeler, R.M.; Locatelli, F.; Fibbe, W.E. Cotransplantation of ex vivo expanded mesenchymal stem cells accelerates lymphocyte recovery and may reduce the risk of graft failure in haploidentical hematopoietic stem-cell transplantation. Blood 2007, 110, 2764-2767. [CrossRef] [PubMed]

42. Robinson, S.N.; Ng, J.; Niu, T.; Yang, H.; McMannis, J.D.; Karandish, S.; Kaur, I.; Fu, P.; Del Angel, M.; Messinger, R.; et al. Superior ex vivo cord blood expansion following co-culture with bone marrow-derived mesenchymal stem cells. Bone Marrow Transplant. 2006, 37, 359-366. [CrossRef] [PubMed]

43. de Lima, M.; McNiece, I.; Robinson, S.N.; Munsell, M.; Eapen, M.; Horowitz, M.; Alousi, A.; Saliba, R.; McMannis, J.D.; Kaur, I.; et al. Cord-blood engraftment with ex vivo mesenchymal-cell coculture. N. Engl. J. Med. 2012, 367, 2305-2315. [CrossRef] [PubMed]

44. Najar, M.; Bouhtit, F.; Melki, R.; Afif, H.; Hamal, A.; Fahmi, H.; Merimi, M.; Lagneaux, L. Mesenchymal stromal cell-based therapy: New perspectives and challenges. J. Clin. Med. 2019, 8, E626. [CrossRef]

45. Birbrair, A.; Frenette, P.S. Niche heterogeneity in the bone marrow. Ann. N. Y. Acad. Sci. 2016, 1370, 82-96. [CrossRef]

46. Szade, K.; Gulati, G.S.; Chan, C.K.F.; Kao, K.S.; Miyanishi, M.; Marjon, K.D.; Sinha, R.; George, B.M.; Chen, J.Y.; Weissman, I.L. Where hematopoietic stem cells live: The bone marrow niche. Antioxid. Redox Signal. 2018, 29, 191-204. [CrossRef]

47. Asada, N.; Takeishi, S.; Frenette, P.S. Complexity of bone marrow hematopoietic stem cell niche. Int. J. Hematol. 2017, 106, 45-54. [CrossRef]

48. Majumdar, M.K.; Thiede, M.A.; Haynesworth, S.E.; Bruder, S.P.; Gerson, S.L. Human marrow-derived mesenchymal stem cells (MSCs) express hematopoietic cytokines and support long-term hematopoiesis when differentiated toward stromal and osteogenic lineages. J. Hematother. Stem Cell Res. 2000, 9, 841-848. [CrossRef]

49. Osugi, M.; Katagiri, W.; Yoshimi, R.; Inukai, T.; Hibi, H.; Ueda, M. Conditioned media from mesenchymal stem cells enhanced bone regeneration in rat calvarial bone defects. Tissue Eng. Part A 2012, 18, 1479-1489. [CrossRef]

50. Calvi, L.M.; Adams, G.B.; Weibrecht, K.W.; Weber, J.M.; Olson, D.P.; Knight, M.C.; Martin, R.P.; Schipani, E.; Divieti, P.; Bringhurst, F.R.; et al. Osteoblastic cells regulate the haematopoietic stem cell niche. Nature 2003, 425, 841-846. [CrossRef]

51. Lampreia, F.P.; Carmelo, J.G.; Anjos-Afonso, F. Notch signaling in the regulation of hematopoietic stem cell. Curr. Stem Cell Rep. 2017, 3, 202-209. [CrossRef]

52. Corselli, M.; Crisan, M.; Murray, I.R.; West, C.C.; Scholes, J.; Codrea, F.; Khan, N.; Peault, B. Identification of perivascular mesenchymal stromal/stem cells by flow cytometry. Cytom. A 2013, 83, 714-720. [CrossRef]

53. Boulais, M.; Soudant, P.; Le Goic, N.; Quere, C.; Boudry, P.; Suquet, M. Involvement of mitochondrial activity and OXPHOS in ATP synthesis during the motility phase of spermatozoa in the pacific oyster, crassostrea gigas. Biol. Reprod. 2015, 93, 118. [CrossRef] [PubMed]

54. Mendez-Ferrer, S.; Lucas, D.; Battista, M.; Frenette, P.S. Haematopoietic stem cell release is regulated by circadian oscillations. Nature 2008, 452, 442-447. [CrossRef]

55. Omatsu, Y.; Sugiyama, T.; Kohara, H.; Kondoh, G.; Fujii, N.; Kohno, K.; Nagasawa, T. The essential functions of adipo-osteogenic progenitors as the hematopoietic stem and progenitor cell niche. Immunity 2010, 33, 387-399. [CrossRef] [PubMed] 
56. Crisan, M.; Huard, J.; Zheng, B.; Sun, B.; Yap, S.; Logar, A.; Giacobino, J.P.; Casteilla, L.; Peault, B. Purification and culture of human blood vessel-associated progenitor cells. Curr. Protoc. Stem Cell Biol. 2008, 4, 2B.2.1-2B.2.13. [CrossRef] [PubMed]

57. Mendelson, A.; Frenette, P.S. Hematopoietic stem cell niche maintenance during homeostasis and regeneration. Nat. Med. 2014, 20, 833-846. [CrossRef] [PubMed]

58. Arinobu, Y.; Mizuno, S.; Chong, Y.; Shigematsu, H.; Iino, T.; Iwasaki, H.; Graf, T.; Mayfield, R.; Chan, S.; Kastner, P.; et al. Reciprocal activation of GATA-1 and PU.1 marks initial specification of hematopoietic stem cells into myeloerythroid and myelolymphoid lineages. Cell Stem Cell 2007, 1, 416-427. [CrossRef]

59. Ehninger, A.; Trumpp, A. The bone marrow stem cell niche grows up: Mesenchymal stem cells and macrophages move in. J. Exp. Med. 2011, 208, 421-428. [CrossRef] [PubMed]

60. Lv, F.J.; Tuan, R.S.; Cheung, K.M.; Leung, V.Y. Concise review: The surface markers and identity of human mesenchymal stem cells. Stem Cells 2014, 32, 1408-1419. [CrossRef]

61. Sorrentino, A.; Ferracin, M.; Castelli, G.; Biffoni, M.; Tomaselli, G.; Baiocchi, M.; Fatica, A.; Negrini, M.; Peschle, C.; Valtieri, M. Isolation and characterization of CD146+ multipotent mesenchymal stromal cells. Exp. Hematol. 2008, 36, 1035-1046. [CrossRef] [PubMed]

62. Russell, K.C.; Phinney, D.G.; Lacey, M.R.; Barrilleaux, B.L.; Meyertholen, K.E.; O'Connor, K.C. In vitro high-capacity assay to quantify the clonal heterogeneity in trilineage potential of mesenchymal stem cells reveals a complex hierarchy of lineage commitment. Stem Cells 2010, 28, 788-798. [CrossRef] [PubMed]

63. Simmons, P.J.; Torok-Storb, B. Identification of stromal cell precursors in human bone marrow by a novel monoclonal antibody, STRO-1. Blood 1991, 78, 55-62. [CrossRef] [PubMed]

64. Bensidhoum, M.; Chapel, A.; Francois, S.; Demarquay, C.; Mazurier, C.; Fouillard, L.; Bouchet, S.; Bertho, J.M.; Gourmelon, P.; Aigueperse, J.; et al. Homing of in vitro expanded Stro-1- or Stro-1+ human mesenchymal stem cells into the NOD/SCID mouse and their role in supporting human CD34 cell engraftment. Blood 2004, 103, 3313-3319. [CrossRef] [PubMed]

65. Gang, E.J.; Bosnakovski, D.; Figueiredo, C.A.; Visser, J.W.; Perlingeiro, R.C. SSEA-4 identifies mesenchymal stem cells from bone marrow. Blood 2007, 109, 1743-1751. [CrossRef]

66. Suila,H.; Pitkanen, V.; Hirvonen, T.; Heiskanen, A.; Anderson, H.; Laitinen, A.; Natunen, S.; Miller-Podraza,H.; Satomaa, T.; Natunen, J.; et al. Are globoseries glycosphingolipids SSEA-3 and -4 markers for stem cells derived from human umbilical cord blood? J. Mol. Cell Biol. 2011, 3, 99-107. [CrossRef]

67. Reinisch, A.; Hernandez, D.C.; Schallmoser, K.; Majeti, R. Generation and use of a humanized bone-marrow-ossicle niche for hematopoietic xenotransplantation into mice. Nat. Protoc. 2017, 12, 2169-2188. [CrossRef]

68. Abarrategi, A.; Mian, S.A.; Passaro, D.; Rouault-Pierre, K.; Grey, W.; Bonnet, D. Modeling the human bone marrow niche in mice: From host bone marrow engraftment to bioengineering approaches. J. Exp. Med. 2018, 215, 729-743. [CrossRef]

69. Krampera, M.; Galipeau, J.; Shi, Y.; Tarte, K.; Sensebe, L.; M. S. C. Committee of the International Society for Cellular Therapy. Immunological characterization of multipotent mesenchymal stromal cells-The International Society for Cellular Therapy (ISCT) working proposal. Cytotherapy 2013, 15, 1054-1061. [CrossRef]

70. Di Nicola, M.; Carlo-Stella, C.; Magni, M.; Milanesi, M.; Longoni, P.D.; Matteucci, P.; Grisanti, S.; Gianni, A.M. Human bone marrow stromal cells suppress T-lymphocyte proliferation induced by cellular or nonspecific mitogenic stimuli. Blood 2002, 99, 3838-3843. [CrossRef]

71. Meisel, R.; Zibert, A.; Laryea, M.; Gobel, U.; Daubener, W.; Dilloo, D. Human bone marrow stromal cells inhibit allogeneic T-cell responses by indoleamine 2,3-dioxygenase-mediated tryptophan degradation. Blood 2004, 103, 4619-4621. [CrossRef] [PubMed]

72. Aggarwal, S.; Pittenger, M.F. Human mesenchymal stem cells modulate allogeneic immune cell responses. Blood 2005, 105, 1815-1822. [CrossRef] [PubMed]

73. Uccelli, A.; Moretta, L.; Pistoia, V. Immunoregulatory function of mesenchymal stem cells. Eur. J. Immunol. 2006, 36, 2566-2573. [CrossRef] [PubMed]

74. Le Blanc, K.; Frassoni, F.; Ball, L.; Locatelli, F.; Roelofs, H.; Lewis, I.; Lanino, E.; Sundberg, B.; Bernardo, M.E.; Remberger, M.; et al. Mesenchymal stem cells for treatment of steroid-resistant, severe, acute graft-versus-host disease: A phase II study. Lancet 2008, 371, 1579-1586. [CrossRef] 
75. Zhou, Y.; Yamamoto, Y.; Xiao, Z.; Ochiya, T. The immunomodulatory functions of mesenchymal stromal/stem cells mediated via paracrine activity. J. Clin. Med. 2019, 8, 1025. [CrossRef] [PubMed]

76. Delaney, C.; Ratajczak, M.Z.; Laughlin, M.J. Strategies to enhance umbilical cord blood stem cell engraftment in adult patients. Expert Rev. Hematol. 2010, 3, 273-283. [CrossRef]

77. Weng, J.Y.; Du, X.; Geng, S.X.; Peng, Y.W.; Wang, Z.; Lu, Z.S.; Wu, S.J.; Luo, C.W.; Guo, R.; Ling, W.; et al. Mesenchymal stem cell as salvage treatment for refractory chronic GVHD. Bone Marrow Transplant. 2010, 45, 1732-1740. [CrossRef]

78. Derakhshani, M.; Abbaszadeh,H.; Movassaghpour, A.A.; Mehdizadeh, A.; Ebrahimi-Warkiani, M.; Yousefi, M. Strategies for elevating hematopoietic stem cells expansion and engraftment capacity. Life Sci. 2019, 232, 116598. [CrossRef]

79. Noort, W.A.; Kruisselbrink, A.B.; In't Anker, P.S.; Kruger, M.; van Bezooijen, R.L.; de Paus, R.A.; Heemskerk, M.H.; Lowik, C.W.; Falkenburg, J.H.; Willemze, R.; et al. Mesenchymal stem cells promote engraftment of human umbilical cord blood-derived CD34(+) cells in NOD/SCID mice. Exp. Hematol. 2002, 30, 870-878. [CrossRef]

80. Almeida-Porada, G.; Porada, C.D.; Tran, N.; Zanjani, E.D. Cotransplantation of human stromal cell progenitors into preimmune fetal sheep results in early appearance of human donor cells in circulation and boosts cell levels in bone marrow at later time points after transplantation. Blood 2000, 95, 3620-3627. [CrossRef]

81. Masuda, S.; Ageyama, N.; Shibata, H.; Obara, Y.; Ikeda, T.; Takeuchi, K.; Ueda, Y.; Ozawa, K.; Hanazono, Y. Cotransplantation with MSCs improves engraftment of HSCs after autologous intra-bone marrow transplantation in nonhuman primates. Exp. Hematol. 2009, 37, 1250-1257. [CrossRef] [PubMed]

82. Kim, E.J.; Kim, N.; Cho, S.G. The potential use of mesenchymal stem cells in hematopoietic stem cell transplantation. Exp. Mol. Med. 2013, 45, e2. [CrossRef] [PubMed]

83. Wagner, W.; Roderburg, C.; Wein, F.; Diehlmann, A.; Frankhauser, M.; Schubert, R.; Eckstein, V.; Ho, A.D. Molecular and secretory profiles of human mesenchymal stromal cells and their abilities to maintain primitive hematopoietic progenitors. Stem Cells 2007, 25, 2638-2647. [CrossRef] [PubMed]

84. Kadekar, D.; Kale, V.; Limaye, L. Differential ability of MSCs isolated from placenta and cord as feeders for supporting ex vivo expansion of umbilical cord blood derived CD34(+) cells. Stem Cell Res. Ther. 2015, 6, 201. [CrossRef] [PubMed]

85. Scotti, C.; Tonnarelli, B.; Papadimitropoulos, A.; Scherberich, A.; Schaeren, S.; Schauerte, A.; Lopez-Rios, J.; Zeller, R.; Barbero, A.; Martin, I. Recapitulation of endochondral bone formation using human adult mesenchymal stem cells as a paradigm for developmental engineering. Proc. Natl. Acad. Sci. USA 2010, 107, 7251-7256. [CrossRef] [PubMed]

86. Occhetta, P.; Pigeot, S.; Rasponi, M.; Dasen, B.; Mehrkens, A.; Ullrich, T.; Kramer, I.; Guth-Gundel, S.; Barbero, A.; Martin, I. Developmentally inspired programming of adult human mesenchymal stromal cells toward stable chondrogenesis. Proc. Natl. Acad. Sci. USA 2018, 115, 4625-4630. [CrossRef]

87. Richardson, S.M.; Walker, R.V.; Parker, S.; Rhodes, N.P.; Hunt, J.A.; Freemont, A.J.; Hoyland, J.A. Intervertebral disc cell-mediated mesenchymal stem cell differentiation. Stem Cells 2006, 24, 707-716. [CrossRef]

88. Rajabzadeh, N.; Fathi, E.; Farahzadi, R. Stem cell-based regenerative medicine. Stem Cell Investig. 2019, 6, 19. [CrossRef]

89. Gunawardena, T.N.A.; Rahman, M.T.; Abdullah, B.J.J.; Kasim, N.H.A. Conditioned media derived from mesenchymal stem cell cultures: The next generation for regenerative medicine. J. Tissue Eng. Regen. Med. 2019, 13, 569-586. [CrossRef]

90. Venkatesh, K.; Sen, D. Mesenchymal stem cells as a source of dopaminergic neurons: A potential cell based therapy for parkinson's disease. Curr. Stem Cell Res. Ther. 2017, 12, 326-347. [CrossRef]

91. Shichinohe,H.; Kawabori, M.; Iijima, H.; Teramoto, T.; Abumiya, T.; Nakayama, N.; Kazumata, K.; Terasaka, S.; Arato, T.; Houkin, K. Research on advanced intervention using novel bone marrOW stem cell (RAINBOW): A study protocol for a phase I, open-label, uncontrolled, dose-response trial of autologous bone marrow stromal cell transplantation in patients with acute ischemic stroke. BMC Neurol. 2017, 17, 179. [CrossRef] [PubMed]

92. Harris, V.K.; Stark, J.; Vyshkina, T.; Blackshear, L.; Joo, G.; Stefanova, V.; Sara, G.; Sadiq, S.A. Phase I trial of intrathecal mesenchymal stem cell-derived neural progenitors in progressive multiple sclerosis. EBioMedicine 2018, 29, 23-30. [CrossRef] [PubMed] 
93. Noronha-Matos, J.B.; Correia-de-Sa, P. Mesenchymal stem cells ageing: Targeting the "purinome" to promote osteogenic differentiation and bone repair. J. Cell Physiol. 2016, 231, 1852-1861. [CrossRef] [PubMed]

94. Samsonraj, R.M.; Raghunath, M.; Nurcombe, V.; Hui, J.H.; van Wijnen, A.J.; Cool, S.M. Concise review: Multifaceted characterization of human mesenchymal stem cells for use in regenerative medicine. Stem Cells Transl. Med. 2017, 6, 2173-2185. [CrossRef] [PubMed]

95. Bahsoun, S.; Coopman, K.; Forsyth, N.R.; Akam, E.C. The role of dissolved oxygen levels on human mesenchymal stem cell culture success, regulatory compliance, and therapeutic potential. Stem Cells Dev. 2018, 27, 1303-1321. [CrossRef]

96. Corradi, G.; Baldazzi, C.; Ocadlikova, D.; Marconi, G.; Parisi, S.; Testoni, N.; Finelli, C.; Cavo, M.; Curti, A.; Ciciarello, M. Mesenchymal stromal cells from myelodysplastic and acute myeloid leukemia patients display in vitro reduced proliferative potential and similar capacity to support leukemia cell survival. Stem Cell Res. Ther. 2018, 9, 271. [CrossRef]

97. Azadniv, M.; Myers, J.R.; McMurray, H.R.; Guo, N.; Rock, P.; Coppage, M.L.; Ashton, J.; Becker, M.W.; Calvi, L.M.; Liesveld, J.L. Bone marrow mesenchymal stromal cells from acute myelogenous leukemia patients demonstrate adipogenic differentiation propensity with implications for leukemia cell support. Leukemia 2019, 1-13. [CrossRef]

98. Geyh, S.; Rodriguez-Paredes, M.; Jager, P.; Khandanpour, C.; Cadeddu, R.P.; Gutekunst, J.; Wilk, C.M.; Fenk, R.; Zilkens, C.; Hermsen, D.; et al. Functional inhibition of mesenchymal stromal cells in acute myeloid leukemia. Leukemia 2016, 30, 683-691. [CrossRef]

99. Desbourdes, L.; Javary, J.; Charbonnier, T.; Ishac, N.; Bourgeais, J.; Iltis, A.; Chomel, J.C.; Turhan, A.; Guilloton, F.; Tarte, K.; et al. Alteration analysis of bone marrow mesenchymal stromal cells from de novo acute myeloid leukemia patients at diagnosis. Stem Cells Dev. 2017, 26, 709-722. [CrossRef]

100. Kode, A.; Manavalan, J.S.; Mosialou, I.; Bhagat, G.; Rathinam, C.V.; Luo, N.; Khiabanian, H.; Lee, A.; Murty, V.V.; Friedman, R.; et al. Leukaemogenesis induced by an activating beta-catenin mutation in osteoblasts. Nature 2014, 506, 240-244. [CrossRef]

101. Kamga, P.T.; Dal Collo, G.; Bassi, G.; Midolo, M.; Delledonne, M.; Chilosi, M.; Bonifacio, M.; Krampera, M. Characterization of a new B-ALL cell line with constitutional defect of the Notch signaling pathway. Oncotarget 2018, 9, 18341-18350. [CrossRef] [PubMed]

102. Diaz de la Guardia, R.; Lopez-Millan, B.; Lavoie, J.R.; Bueno, C.; Castano, J.; Gomez-Casares, M.; Vives, S.; Palomo, L.; Juan, M.; Delgado, J.; et al. Detailed characterization of mesenchymal stem/stromal cells from a large cohort of AML patients demonstrates a definitive link to treatment outcomes. Stem Cell Rep. 2017, 8 , 1573-1586. [CrossRef] [PubMed]

103. Brenner, A.K.; Nepstad, I.; Bruserud, O. Mesenchymal stem cells support survival and proliferation of primary human acute myeloid leukemia cells through heterogeneous molecular mechanisms. Front. Immunol. 2017, 8, 106. [CrossRef] [PubMed]

104. Gnani, D.; Crippa, S.; Della Volpe, L.; Rossella, V.; Conti, A.; Lettera, E.; Rivis, S.; Ometti, M.; Fraschini, G.; Bernardo, M.E.; et al. An early-senescence state in aged mesenchymal stromal cells contributes to hematopoietic stem and progenitor cell clonogenic impairment through the activation of a pro-inflammatory program. Aging Cell 2019, 18, e12933. [CrossRef] [PubMed]

105. Wagner, W.; Horn, P.; Castoldi, M.; Diehlmann, A.; Bork, S.; Saffrich, R.; Benes, V.; Blake, J.; Pfister, S.; Eckstein, V.; et al. Replicative senescence of mesenchymal stem cells: A continuous and organized process. PLOS ONE 2008, 3, e2213. [CrossRef] [PubMed]

106. Velarde, M.C.; Demaria, M.; Campisi, J. Senescent cells and their secretory phenotype as targets for cancer therapy. Interdiscip. Top Gerontol. 2013, 38, 17-27.

107. Davalos, A.R.; Coppe, J.P.; Campisi, J.; Desprez, P.Y. Senescent cells as a source of inflammatory factors for tumor progression. Cancer Metastasis Rev. 2010, 29, 273-283. [CrossRef] [PubMed]

108. Geyh, S.; Oz, S.; Cadeddu, R.P.; Fröbel, J.; Brückner, B.; Kündgen, A.; Fenk, R.; Bruns, I.; Zilkens, C.; Hermsen, D.; et al. Insufficient stromal support in MDS results from molecular and functional deficits of mesenchymal stromal cells. Leukemia 2013, 27, 1841-1851. [CrossRef]

109. Mattiucci, D.; Maurizi, G.; Leoni, P.; Poloni, A. Aging- and senescence-associated changes of mesenchymal stromal cells in myelodysplastic syndromes. Cell Transplant. 2018, 27, 754-764. [CrossRef] 
110. O’Hagan-Wong, K.; Nadeau, S.; Carrier-Leclerc, A.; Apablaza, F.; Hamdy, R.; Shum-Tim, D.; Rodier, F.; Colmegna, I. Increased IL-6 secretion by aged human mesenchymal stromal cells disrupts hematopoietic stem and progenitor cells' homeostasis. Oncotarget 2016, 7, 13285-13296. [CrossRef]

111. Zhao, S.; Guo, J.; Fei, C.; Zheng, Q.; Li, X.; Chang, C. Downregulation of MMP1 in MDS-derived mesenchymal stromal cells reduces the capacity to restrict MDS cell proliferation. Sci. Rep. 2017, 7, 43849. [CrossRef] [PubMed]

112. Deeg, H.J. Hematopoietic cell transplantation for myelodysplastic syndrome. Am. Soc. Clin. Oncol. Educ. Book 2015, 35, e375-e380. [CrossRef] [PubMed]

113. Klaus, M.; Stavroulaki, E.; Kastrinaki, M.C.; Fragioudaki, P.; Giannikou, K.; Psyllaki, M.; Pontikoglou, C.; Tsoukatou, D.; Mamalaki, C.; Papadaki, H.A. Reserves, functional, immunoregulatory, and cytogenetic properties of bone marrow mesenchymal stem cells in patients with myelodysplastic syndromes. Stem Cells Dev. 2010, 19, 1043-1054. [CrossRef] [PubMed]

114. Fracchiolla, N.S.; Fattizzo, B.; Cortelezzi, A. Mesenchymal stem cells in myeloid malignancies: A focus on immune escaping and therapeutic implications. Stem Cells Int. 2017, 2017, 6720594. [CrossRef]

115. Zhao, Z.G.; Xu, W.; Yu, H.P.; Fang, B.L.; Wu, S.H.; Li, F.; Li, W.M.; Li, Q.B.; Chen, Z.C.; Zou, P. Functional characteristics of mesenchymal stem cells derived from bone marrow of patients with myelodysplastic syndromes. Cancer Lett. 2012, 317, 136-143. [CrossRef]

116. Wang, Z.; Tang, X.; Xu, W.; Cao, Z.; Sun, L.; Li, W.; Li, Q.; Zou, P.; Zhao, Z. The different immunoregulatory functions on dendritic cells between mesenchymal stem cells derived from bone marrow of patients with low-risk or high-risk myelodysplastic syndromes. PLoS ONE 2013, 8, e57470. [CrossRef]

117. Ciciarello, M.; Corradi, G.; Loscocco, F.; Visani, G.; Monaco, F.; Cavo, M.; Curti, A.; Isidori, A. The yin and yang of the bone marrow microenvironment: pros and cons of mesenchymal stromal cells in acute myeloid leukemia. Front. Oncol. 2019, 9, 1135. [CrossRef]

118. Vicente López, Á.; Vázquez García, M.N.; Melen, G.J.; Entrena Martínez, A.; Cubillo Moreno, I.; García-Castro, J.; Orellana, M.R.; González, A.G. Mesenchymal stromal cells derived from the bone marrow of acute lymphoblastic leukemia patients show altered BMP4 production: Correlations with the course of disease. PLoS ONE 2014, 9, e84496. [CrossRef]

119. Vilchis-Ordoñez, A.; Contreras-Quiroz, A.; Vadillo, E.; Dorantes-Acosta, E.; Reyes-López, A.; Quintela-Nuñez del Prado, H.M.; Venegas-Vázquez, J.; Mayani, H.; Ortiz-Navarrete, V.; López-Martínez, B.; et al. Bone marrow cells in acute lymphoblastic leukemia create a proinflammatory microenvironment influencing normal hematopoietic differentiation fates. BioMed Res. Int. 2015, 2015, 386165. [CrossRef]

120. Burt, R.; Dey, A.; Aref, S.; Aguiar, M.; Akarca, A.; Bailey, K.; Day, W.; Hooper, S.; Kirkwood, A.; Kirschner, K.; et al. Activated stromal cells transfer mitochondria to rescue acute lymphoblastic leukaemia cells from oxidative stress. Blood 2019, 134, 1415-1429. [CrossRef]

121. Raaijmakers, M.H.; Mukherjee, S.; Guo, S.; Zhang, S.; Kobayashi, T.; Schoonmaker, J.A.; Ebert, B.L.; Al-Shahrour, F.; Hasserjian, R.P.; Scadden, E.O.; et al. Bone progenitor dysfunction induces myelodysplasia and secondary leukaemia. Nature 2010, 464, 852-857. [CrossRef] [PubMed]

122. Santamaría, C.; Muntión, S.; Rosón, B.; Blanco, B.; López-Villar, O.; Carrancio, S.; Sánchez-Guijo, F.M.; Díez-Campelo, M.; Alvarez-Fernández, S.; Sarasquete, M.E.; et al. Impaired expression of DICER, DROSHA, SBDS and some microRNAs in mesenchymal stromal cells from myelodysplastic syndrome patients. Haematologica 2012, 97, 1218-1224. [CrossRef] [PubMed]

123. Rupec, R.A.; Jundt, F.; Rebholz, B.; Eckelt, B.; Weindl, G.; Herzinger, T.; Flaig, M.J.; Moosmann, S.; Plewig, G.; Dörken, B.; et al. Stroma-mediated dysregulation of myelopoiesis in mice lacking I kappa B alpa. Immunity 2005, 22, 479-491. [CrossRef] [PubMed]

124. Tohda, S.; Nara, N. Expression of Notch1 and Jagged1 proteins in acute myeloid leukemia cells. Leuk. Lymphoma 2001, 42, 467-472. [CrossRef]

125. Walkley, C.R.; Shea, J.M.; Sims, N.A.; Purton, L.E.; Orkin, S.H. Rb regulates interactions between hematopoietic stem cells and their bone marrow microenvironment. Cell 2007, 129, 1081-1095. [CrossRef]

126. Zandecki, M.; Facon, T.; Preudhomme, C.; Vanrumbeke, M.; Vachee, A.; Quesnel, B.; Lai, J.L.; Cosson, A.; Fenaux, P. The retinoblastoma gene (RB-1) status in multiple myeloma: A report on 35 cases. Leuk. Lymphoma 1995, 18, 497-503. [CrossRef]

127. Hideshima, T.; Anderson, K.C. Molecular mechanisms of novel therapeutic approaches for multiple myeloma. Nat. Rev. Cancer 2002, 2, 927-937. [CrossRef] 
128. Mitsiades, C.S.; Mitsiades, N.S.; Munshi, N.C.; Richardson, P.G.; Anderson, K.C. The role of the bone microenvironment in the pathophysiology and therapeutic management of multiple myeloma: Interplay of growth factors, their receptors and stromal interactions. Eur. J. Cancer 2006, 42, 1564-1573. [CrossRef]

129. Giuliani, N.; Colla, S.; Sala, R.; Moroni, M.; Lazzaretti, M.; La Monica, S.; Bonomini, S.; Hojden, M.; Sammarelli, G.; Barillè, S.; et al. Human myeloma cells stimulate the receptor activator of nuclear factor-kappa B ligand (RANKL) in T lymphocytes: A potential role in multiple myeloma bone disease. Blood 2002, 100, 4615-4621. [CrossRef]

130. Pearse, R.N.; Sordillo, E.M.; Yaccoby, S.; Wong, B.R.; Liau, D.F.; Colman, N.; Michaeli, J.; Epstein, J.; Choi, Y. Multiple myeloma disrupts the TRANCE/ osteoprotegerin cytokine axis to trigger bone destruction and promote tumor progression. Proc. Natl. Acad. Sci. USA 2001, 98, 11581-11586. [CrossRef]

131. Schwarz, E.M.; Ritchlin, C.T. Clinical development of anti-RANKL therapy. Arthritis Res. Ther. 2007, 9 (Suppl. 1), S7. [CrossRef] [PubMed]

132. Ring, E.S.; Lawson, M.A.; Snowden, J.A.; Jolley, I.; Chantry, A.D. New agents in the treatment of myeloma bone disease. Calcif. Tissue Int. 2018, 102, 196-209. [CrossRef] [PubMed]

133. Goldstein, D.A. Denosumab for bone lesions in multiple myeloma-what is its value? Haematologica 2018, 103, 753-754. [CrossRef] [PubMed]

134. Qiang, Y.W.; Chen, Y.; Stephens, O.; Brown, N.; Chen, B.; Epstein, J.; Barlogie, B.; Shaughnessy, J.D. Myeloma-derived Dickkopf-1 disrupts Wnt-regulated osteoprotegerin and RANKL production by osteoblasts: A potential mechanism underlying osteolytic bone lesions in multiple myeloma. Blood 2008, 112, 196-207. [CrossRef] [PubMed]

135. Pinzone, J.J.; Hall, B.M.; Thudi, N.K.; Vonau, M.; Qiang, Y.W.; Rosol, T.J.; Shaughnessy, J.D. The role of Dickkopf-1 in bone development, homeostasis, and disease. Blood 2009, 113, 517-525. [CrossRef]

136. Mitsiades, C.S.; Mitsiades, N.S.; McMullan, C.J.; Poulaki, V.; Shringarpure, R.; Akiyama, M.; Hideshima, T.; Chauhan, D.; Joseph, M.; Libermann, T.A.; et al. Inhibition of the insulin-like growth factor receptor-1 tyrosine kinase activity as a therapeutic strategy for multiple myeloma, other hematologic malignancies, and solid tumors. Cancer Cell 2004, 5, 221-230. [CrossRef]

137. Schepers, K.; Pietras, E.M.; Reynaud, D.; Flach, J.; Binnewies, M.; Garg, T.; Wagers, A.J.; Hsiao, E.C.; Passegué, E. Myeloproliferative neoplasia remodels the endosteal bone marrow niche into a self-reinforcing leukemic niche. Cell Stem Cell 2013, 13, 285-299. [CrossRef]

138. Borrello, I. Can we change the disease biology of multiple myeloma? Leuk. Res. 2012, 36 (Suppl. 1), S3-S12. [CrossRef]

139. Jourdan, M.; Tarte, K.; Legouffe, E.; Brochier, J.; Rossi, J.F.; Klein, B. Tumor necrosis factor is a survival and proliferation factor for human myeloma cells. Eur. Cytokine Netw. 1999, 10, 65-70.

140. Di Marzo, L.; Desantis, V.; Solimando, A.G.; Ruggieri, S.; Annese, T.; Nico, B.; Fumarulo, R.; Vacca, A.; Frassanito, M.A. Microenvironment drug resistance in multiple myeloma: Emerging new players. Oncotarget 2016, 7, 60698-60711. [CrossRef]

141. Malfuson, J.V.; Boutin, L.; Clay, D.; Thépenier, C.; Desterke, C.; Torossian, F.; Guerton, B.; Anginot, A.; de Revel, T.; Lataillade, J.J.; et al. SP/drug efflux functionality of hematopoietic progenitors is controlled by mesenchymal niche through VLA-4/CD44 axis. Leukemia 2014, 28, 853-864. [CrossRef] [PubMed]

142. Mrozik, K.M.; Blaschuk, O.W.; Cheong, C.M.; Zannettino, A.C.W.; Vandyke, K. N-cadherin in cancer metastasis, its emerging role in haematological malignancies and potential as a therapeutic target in cancer. BMC Cancer 2018, 18, 939. [CrossRef] [PubMed]

143. Gado, K.; Domjan, G.; Hegyesi, H.; Falus, A. Role of INTERLEUKIN-6 in the pathogenesis of multiple myeloma. Cell Biol. Int. 2000, 24, 195-209. [CrossRef] [PubMed]

144. Rossi, J.F.; Lu, Z.Y.; Jourdan, M.; Klein, B. Interleukin-6 as a therapeutic target. Clin. Cancer Res. 2015, 21, 1248-1257. [CrossRef]

145. Burger, J.A.; Kipps, T.J. CXCR4: A key receptor in the crosstalk between tumor cells and their microenvironment. Blood 2006, 107, 1761-1767. [CrossRef]

146. Plaks, V.; Kong, N.; Werb, Z. The cancer stem cell niche: How essential is the niche in regulating stemness of tumor cells? Cell Stem Cell 2015, 16, 225-238. [CrossRef]

147. Redondo-Munoz, J.; Garcia-Pardo, A.; Teixido, J. Molecular players in hematologic tumor cell trafficking. Front. Immunol. 2019, 10, 156. [CrossRef] 
148. Azab, A.K.; Runnels, J.M.; Pitsillides, C.; Moreau, A.S.; Azab, F.; Leleu, X.; Jia, X.; Wright, R.; Ospina, B.; Carlson, A.L.; et al. CXCR4 inhibitor AMD3100 disrupts the interaction of multiple myeloma cells with the bone marrow microenvironment and enhances their sensitivity to therapy. Blood 2009, 113, 4341-4351. [CrossRef]

149. Mori, Y.; Shimizu, N.; Dallas, M.; Niewolna, M.; Story, B.; Williams, P.J.; Mundy, G.R.; Yoneda, T. Anti-alpha4 integrin antibody suppresses the development of multiple myeloma and associated osteoclastic osteolysis. Blood 2004, 104, 2149-2154. [CrossRef]

150. Burger, R. Impact of interleukin-6 in hematological malignancies. Transfus. Med. Hemotherapy 2013, 40, 336-343. [CrossRef]

151. Portier, M.; Zhang, X.G.; Caron, E.; Lu, Z.Y.; Bataille, R.; Klein, B. gamma-Interferon in multiple myeloma: Inhibition of interleukin-6 (IL-6)-dependent myeloma cell growth and downregulation of IL-6-receptor expression in vitro. Blood 1993, 81, 3076-3082. [CrossRef] [PubMed]

152. Chen, Y.H.; Desai, P.; Shiao, R.T.; Lavelle, D.; Haleem, A.; Chen, J. Inhibition of myeloma cell growth by dexamethasone and all-trans retinoic acid: Synergy through modulation of interleukin- 6 autocrine loop at multiple sites. Blood 1996, 87, 314-323. [CrossRef] [PubMed]

153. Ho, M.; Chen, T.; Liu, J.; Dowling, P.; Hideshima, T.; Zhang, L.; Morelli, E.; Camci-Unal, G.; Wu, X.; Tai, Y.T.; et al. Targeting histone deacetylase 3 (HDAC3) in the bone marrow microenvironment inhibits multiple myeloma proliferation by modulating exosomes and IL-6 trans-signaling. Leukemia 2019. [CrossRef] [PubMed]

154. Mitsiades, N.; Mitsiades, C.S.; Richardson, P.G.; McMullan, C.; Poulaki, V.; Fanourakis, G.; Schlossman, R.; Chauhan, D.; Munshi, N.C.; Hideshima, T.M.; et al. Molecular sequelae of histone deacetylase inhibition in human malignant B cells. Blood 2003, 101, 4055-4062. [CrossRef] [PubMed]

155. Simmons, P.J.; Przepiorka, D.; Thomas, E.D.; Torok-Storb, B. Host origin of marrow stromal cells following allogeneic bone marrow transplantation. Nature 1987, 328, 429-432. [CrossRef]

156. Marsh, J.C.; Harhalakis, N.; Dowding, C.; Laffan, M.; Gordon-Smith, E.C.; Hows, J.M. Recurrent graft failure following syngeneic bone marrow transplantation for aplastic anaemia. Bone Marrow Transplant. 1989, 4 , $581-585$.

157. Witherspoon, R.P.; Schubach, W.; Neiman, P.; Martin, P.; Thomas, E.D. Donor cell leukemia developing six years after marrow grafting for acute leukemia. Blood 1985, 65, 1172-1174. [CrossRef]

158. Lawler, M.; Locasciulli, A.; Longoni, D.; Schiro, R.; McCann, S.R. Leukaemic transformation of donor cells in a patient receiving a second allogeneic bone marrow transplant for severe aplastic anaemia. Bone Marrow Transplant. 2002, 29, 453-456. [CrossRef]

159. McCann, S.R.; Bacigalupo, A.; Gluckman, E.; Hinterberger, W.; Hows, J.; Ljungman, P.; Marin, P.; Nissen, C.; van't Veer Kerthof, E.; Raghavachar, A.; et al. Graft rejection and second bone marrow transplants for acquired aplastic anaemia: A report from the Aplastic Anaemia Working Party of the European Bone Marrow Transplant Group. Bone Marrow Transplant. 1994, 13, $233-237$.

160. Cavazzana, M.; Bushman, F.D.; Miccio, A.; Andre-Schmutz, I.; Six, E. Gene therapy targeting haematopoietic stem cells for inherited diseases: Progress and challenges. Nat. Rev. Drug Discov. 2019, 18, 447-462. [CrossRef]

161. Cavazzana, M.; Ribeil, J.A.; Lagresle-Peyrou, C.; Andre-Schmutz, I. Gene therapy with hematopoietic stem cells: The diseased bone marrow's point of view. Stem Cells Dev. 2017, 26, 71-76. [CrossRef] [PubMed]

162. Kovtonyuk, L.V.; Fritsch, K.; Feng, X.; Manz, M.G.; Takizawa, H. Inflamm-aging of hematopoiesis, hematopoietic stem cells, and the bone marrow microenvironment. Front. Immunol. 2016, 7, 502. [CrossRef] [PubMed]

163. Gillet, N.A.; Malani, N.; Melamed, A.; Gormley, N.; Carter, R.; Bentley, D.; Berry, C.; Bushman, F.D.; Taylor, G.P.; Bangham, C.R. The host genomic environment of the provirus determines the abundance of HTLV-1-infected T-cell clones. Blood 2011, 117, 3113-3122. [CrossRef] [PubMed]

164. Ho, Y.H.; Del Toro, R.; Rivera-Torres, J.; Rak, J.; Korn, C.; García-García, A.; Macías, D.; González-Gómez, C.; Del Monte, A.; Wittner, M.; et al. Remodeling of bone marrow hematopoietic stem cell niches promotes myeloid cell expansion during premature or physiological aging. Cell Stem Cell 2019, 25, 407-418. [CrossRef] [PubMed]

165. Aiuti, A.; Naldini, L. Safer conditioning for blood stem cell transplants. Nat. Biotechnol. 2016, 34, 721-723. [CrossRef] [PubMed] 
166. Ingo, D.M.; Redaelli, D.; Rossella, V.; Perini, O.; Santoleri, L.; Ciceri, F.; Aiuti, A.; Bernardo, M.E. Bone marrow-derived CD34(-) fraction: A rich source of mesenchymal stromal cells for clinical application. Cytotherapy 2016, 18, 1560-1563. [CrossRef] [PubMed]

167. Starc, N.; Ingo, D.; Conforti, A.; Rossella, V.; Tomao, L.; Pitisci, A.; De Mattia, F.; Brigida, I.; Algeri, M.; Montanari, M.; et al. Biological and functional characterization of bone marrow-derived mesenchymal stromal cells from patients affected by primary immunodeficiency. Sci. Rep. 2017, 7, 8153. [CrossRef]

168. Weisser, M.; Demel, U.M.; Stein, S.; Chen-Wichmann, L.; Touzot, F.; Santilli, G.; Sujer, S.; Brendel, C.; Siler, U.; Cavazzana, M.; et al. Hyperinflammation in patients with chronic granulomatous disease leads to impairment of hematopoietic stem cell functions. J. Allergy Clin. Immunol. 2016, 138, 219-228. [CrossRef]

169. Giugliani, R.; Federhen, A.; Rojas, M.V.; Vieira, T.; Artigalás, O.; Pinto, L.L.; Azevedo, A.C.; Acosta, A.; Bonfim, C.; Lourenço, C.M.; et al. Mucopolysaccharidosis I, II, and VI: Brief review and guidelines for treatment. Genet. Mol. Biol. 2010, 33, 589-604. [CrossRef]

170. Gatto, F.; Redaelli, D.; Salvadè, A.; Marzorati, S.; Sacchetti, B.; Ferina, C.; Roobrouck, V.D.; Bertola, F.; Romano, M.; Villani, G.; et al. Hurler disease bone marrow stromal cells exhibit altered ability to support osteoclast formation. Stem Cells Dev. 2012, 21, 1466-1477. [CrossRef]

171. Takamatsu, Y.; Simmons, P.J.; Moore, R.J.; Morris, H.A.; To, L.B.; Lévesque, J.P. Osteoclast-mediated bone resorption is stimulated during short-term administration of granulocyte colony-stimulating factor but is not responsible for hematopoietic progenitor cell mobilization. Blood 1998, 92, 3465-3473. [CrossRef] [PubMed]

172. Lymperi, S.; Ersek, A.; Ferraro, F.; Dazzi, F.; Horwood, N.J. Inhibition of osteoclast function reduces hematopoietic stem cell numbers in vivo. Blood 2011, 117, 1540-1549. [CrossRef] [PubMed]

173. Mansour, A.; Abou-Ezzi, G.; Sitnicka, E.; Jacobsen, S.E.; Wakkach, A.; Blin-Wakkach, C. Osteoclasts promote the formation of hematopoietic stem cell niches in the bone marrow. J. Exp. Med. 2012, 209, 537-549. [CrossRef] [PubMed]

174. Crippa, S.; Rossella, V.; Aprile, A.; Silvestri, L.; Rivis, S.; Scaramuzza, S.; Pirroni, S.; Avanzini, M.A.; Basso-Ricci, L.; Hernandez, R.J.; et al. Bone marrow stromal cells from beta-thalassemia patients have impaired hematopoietic supportive capacity. J. Clin. Investig. 2019, 129, 1566-1580. [CrossRef] [PubMed]

175. Gaziev, D.; Polchi, P.; Galimberti, M.; Angelucci, E.; Giardini, C.; Baronciani, D.; Erer, B.; Lucarelli, G. Graft-versus-host disease after bone marrow transplantation for thalassemia: An analysis of incidence and risk factors. Transplantation 1997, 63, 854-860. [CrossRef] [PubMed]

176. Fouzia, N.; Edison, E.; Lakshmi, K.M.; Korula, A.; Velayudhan, S.R.; Balasubramanian, P.; Abraham, A.; Viswabandya, A.; George, B.; Mathews, V.; et al. Long-term outcome of mixed chimerism after stem cell transplantation for thalassemia major conditioned with busulfan and cyclophosphamide. Bone Marrow Transplant. 2018, 53, 169-174. [CrossRef] [PubMed]

177. Liu, Z.; Zhang, Y.; Xiao, H.; Yao, Z.; Zhang, H.; Liu, Q.; Wu, B.; Nie, D.; Li, Y.; Pang, Y.; et al. Cotransplantation of bone marrow-derived mesenchymal stem cells in haploidentical hematopoietic stem cell transplantation in patients with severe aplastic anemia: An interim summary for a multicenter phase II trial results. Bone Marrow Transplant. 2017, 52, 1080. [CrossRef] [PubMed]

178. Alagesan, S.; Griffin, M.D. Autologous and allogeneic mesenchymal stem cells in organ transplantation: What do we know about their safety and efficacy? Curr. Opin. Organ. Transplant. 2014, 19, 65-72. [CrossRef]

(C) 2019 by the authors. Licensee MDPI, Basel, Switzerland. This article is an open access article distributed under the terms and conditions of the Creative Commons Attribution (CC BY) license (http://creativecommons.org/licenses/by/4.0/). 